\title{
THE SYLLIDAE (POLYCHAETOUS ANNELIDS) FROM JAPAN (IV) - SYLLINAE (1)-
}

$\operatorname{AUTHOR}(\mathrm{S}):$

Imajima, Minoru

\section{CITATION:}

Imajima, Minoru. THE SYLLIDAE (POLYCHAETOUS ANNELIDS) FROM JAPAN (IV) -SYLLINAE (1)-. PUBLICATIONS OF THE SETO MARINE BIOLOGICAL LABORATORY 1966, 14(3): 219-252

ISSUE DATE:

1966-07-20

URL:

http://hdl.handle.net/2433/175436

RIGHT: 


\title{
THE SYLLIDAE (POLYCHAETOUS ANNELIDS) FROM JAPAN (IV)* SYLLINAE (1)
}

\author{
MinoRU IMAJIMA
}

National Science Museum, Tokyo

With 12 Text-figures

\section{Subfamily SYLLINAE RIOJA, 1925}

The subfamily SYLLINAE is the largest group of SYLLIDAE. Eight genera are represented in Japan; they are Opisthosyllis Langerhans; Haplosyllis Langerhans; Geminosyllis new genus; Trypanosyllis Claparède; Syllis Savigny; Parasphaerosyllis Monro; Langerhansia Czernlavsky; Typosyllis Langerhans. Langerhansia is newly added to the Japanese fauna.

Trypanosyllis (Trypanoseta) Imajima and Hartman (1964) is referred to Geminosyllis new genus because the body is cylindrical and the pharynx has a trepan. Seven species of SYLIINAE previously reported (FAUveL, 1934) from Seto and Misaki are revised (below): Syllis (Typosyllis) Krohnii and Syllis (Typosyllis) fasciata $=$ Typosyllis ehlersioides Marenzelder; Syllis (Typosyllis) exilis=Typosyllis maculata n. sp.; Syllis (Typosyllis) closterobranchia $=$ Typosyllis aciculata orientalis IMAJIMA and HARTMAn; Syllis (Typosyllis) torquata $=$ Typosyllis monilata n. sp.; syllis (Typosyllis) inflata $=$ Typosyllis nipponica n. sp. and Trypanosyllis zebra=Trypanosyllis (Trypanedenta) taeniaformis (HASWELL).

\section{Key to genera of SYLLINAE from Japan}

1. Body depressed dorso-ventrally; pharynx with chitinous, coarsely denticulate crown or trepan; dorsal cirri thick and with many short articles $\ldots \ldots \ldots \ldots \ldots \ldots \ldots \ldots \ldots$ Trypanosyllis

1. Body subcylindrical; pharynx with trepan and a middorsal tooth; dorsal cirri slender. . Geminosyllis

1. Body subcylindrical; pharynx without trepan but with a middorsal tooth; dorsal cirri slender ..2

2. Pharynx with a middorsal tooth in posterior position............... Opisthosyllis

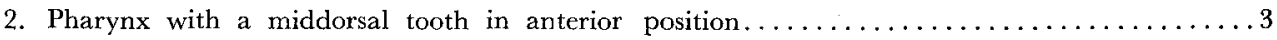

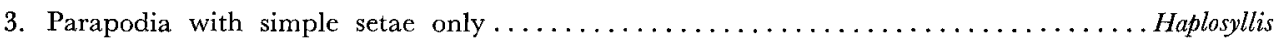

3. Parapodia with compound setae and simple or pseudocompound setae...........Syllis

3. Parapodia with compound setae and two additional simple setae $\ldots \ldots \ldots \ldots \ldots \ldots \ldots \ldots$

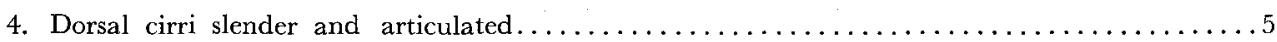

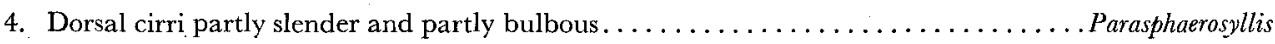

5. Composite setae entirely falcigerous $\ldots \ldots \ldots \ldots \ldots \ldots \ldots \ldots \ldots \ldots \ldots \ldots \ldots \ldots \ldots$ Typosy

5. Composite setae partly falcigerous, partly spinigerous $\ldots \ldots \ldots \ldots \ldots \ldots \ldots \ldots$ Langerhansia

* Continued from Part 3 (XIV (2), pp. 85-116).

Publ. Seto Mar. Biol. Lab., XIV (3), 219-252, 1966. (Article 18) 


\section{Haplosyllis LANGERHANS, 1879}

\section{Type: Haplosyllis spongicola (GRUBE, 1855)}

The body is depressed cylindrical. The prostomium is subglobular and has two pairs of eyes. Three antennae, tentacular cirri and dorsal cirri are slender and distinctly articulated. Palpi are broadly triangular. The pharynx is surrounded by 10 soft papillae; the anterior margin of its inner wall is smooth and has a subdistal, middorsal tooth. Parapodia are short conical or long subcylindrical. Setae number 1 to 4 in a fascicle; each is simple, distally bifid and has a lateral boss.

Key to species of Haplosyllis from Japan

1. Dorsal cirri rudimentary and not annulated except in first ten parapodia...............

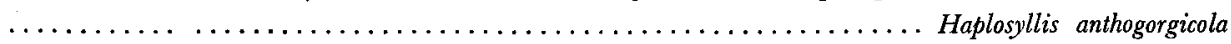

1. Dorsal cirri developed and annulated throughout the body $\ldots \ldots \ldots \ldots \ldots \ldots \ldots \ldots \ldots \ldots$

2. Dorsal cirri vith 7 to 9 articles in median parapodia.............. Haplosyllis spongicola

2. Dorsal cirri vith 19 to 47 articles in median parapodia ......... Haplosyllis spongicola tentaculata

\section{Haplosyllis anthogorgicola UTINOMI, 1956}

Haplosyllis anthogorgiola Utinomi, 1956, pp. 247-249, fig. 2; Imajima and HaRtman, 1964, pp. 119120.

Occurrence: Seto, from Anthogorgia bocki, a gorgonacean.

Diagnosis: The longest specimen measures about $3 \mathrm{~mm}$ long and 0.18 to $0.24 \mathrm{~mm}$ wide; it consists of 38 to 42 segments. A median antenna is more than four times as long as the prostomium and consists of 15 annulations; the lateral ones are about half as long as the median one and each has 10 annulations. Palpi are fused only at their bases. The proventriculus extends from segment 4 to 7 , or through 4 segments. The first 10 parapodia have alternating long and short dorsal cirri and those farther back gradually diminish in size and are not annulated. Acicula occur singly and each terminates in a hooked tip. A simple seta with a laterally projecting tooth is present just below the aciculum.

Distribution: Southern Japan.

\section{Haplosyllis spongicola (GRUBE, 1855)}

(Text-fig. 38, a-h)

Syllis (Haplosyllis) spongicola FAUveL, 1923, pp. 257-258, fig. 95, a-d; 1934, p. 302; 1953, p. 147, fig. 75, a-d.

Haplosyllis spongicola Hartman, 1945, pp. 15-16; 1951, p. 4.

Syllis spongicola spongicola CognetTr, 1957, pp. 10-12, fig. 2a.

Collection: Usa, from ascidians; Onagawa; Sugashima; Seto; Mukaishima; Tamano; Noto-ogi, from sponges; Uraga Strait, in 20 to $60 \mathrm{~m}$. 
Description: Specimens from Usa mainly collected among ascidians measure 26 to $28 \mathrm{~mm}$ long and $1.2 \mathrm{~mm}$ wide for 102 to 110 setigerous segments. Those from Seto and Mukaishima were collected among sponges and measure 3 to $6 \mathrm{~mm}$ long and 0.6 $\mathrm{mm}$ wide for 29 to 40 setigerous segments. The body is orange in life. The prostomium is subglobular and has two pairs of reddish eyes in trapezoidal arrangement (fig. a); the anterior are larger than the posterior ones. A median antenna arises from the center of the prostomium and is about twice as long as the prostomium; it has 16 to 18 annulations. Lateral antennae arise from the anterior margin of the prostomium and each has 12 to 13 articles. Palpi are subtriangular and about as long as the prostomium; their bases are fused. The pharynx is distally surrounded by 10 soft papillae and the anterior margin is smooth; it has a middorsal chitinized tooth. The proventriculus is ellipsoidal and extends between 8 to 9 and 13 to 15 setigerous segments in specimens from Usa, and from the 6th setigerous segment through 4 or 5 segments for those from Mukaishima. Dorsal tentacular cirri are about as long as the lateral antennae and ventral cirri are about half as long as dorsal ones. The first dorsal cirri are slender and have 12 to 18 annulations (fig. b). The second and third cirri are short, with 7 to 10 annulations. The fourth cirri are long and have 12 annulations. The succeeding cirri alternate slightly long, with 9, and short with 7 articles and each is about half to two-thirds as long as the body is wide. In the specimens from Usa, annulations of dorsal cirri become gradually indistinct posteriorly (fig. c); however, in small individuals from Mukaishima dorsal cirri are distinctly annulated throughout the body. (fig. d). Parapodia are bluntly conical and have fascicles of 2 to 4 simple setae; each seta is a thick hook with bifid tip with a lateral boss; the cutting margin has or lacks minute serrations (fig. e). Setae from the first parapodium are slender; each has a smaller lateral enlargement (fig. f). Ventral cirri are digitate and extend beyond the tips of the setigerous lobes. Acicula number two in all parapodia; one is distally bent and the other straight (figs. g, h).

Distribution: Mediterranean Sea; Red Sea; Atlantic and Indian Oceans; southern California to Panama; Gulf of Mexico; West Indian region; southern Japan.

\section{Haplosyllis spongicola tentaculata (MARION, 1879)}

('Text-fig. 38, i-n)

Syllis spongicola var. tentaculata MARton, 1879, p. 19.

Syllis spongicola tentaculata Cognetтr, 1954, pp. 1-3, fig. lb; 1957, pp. 12-13, fig. 2b.

Collection: Ariake Sea, in 10 and $50 \mathrm{~m}$.

Description: Two anterior fragments were examined; they measure $9 \mathrm{~mm}$ long by $1.2 \mathrm{~mm}$ wide and $10 \mathrm{~mm}$ long by $1.3 \mathrm{~mm}$ wide, and consist of 29 to 40 setigerous segments. The body is reddish brown, without color markings in preserved specimen. The prostomium is depressed triangular; there are two pairs of eyes (fig. i). A 
M. Imajima
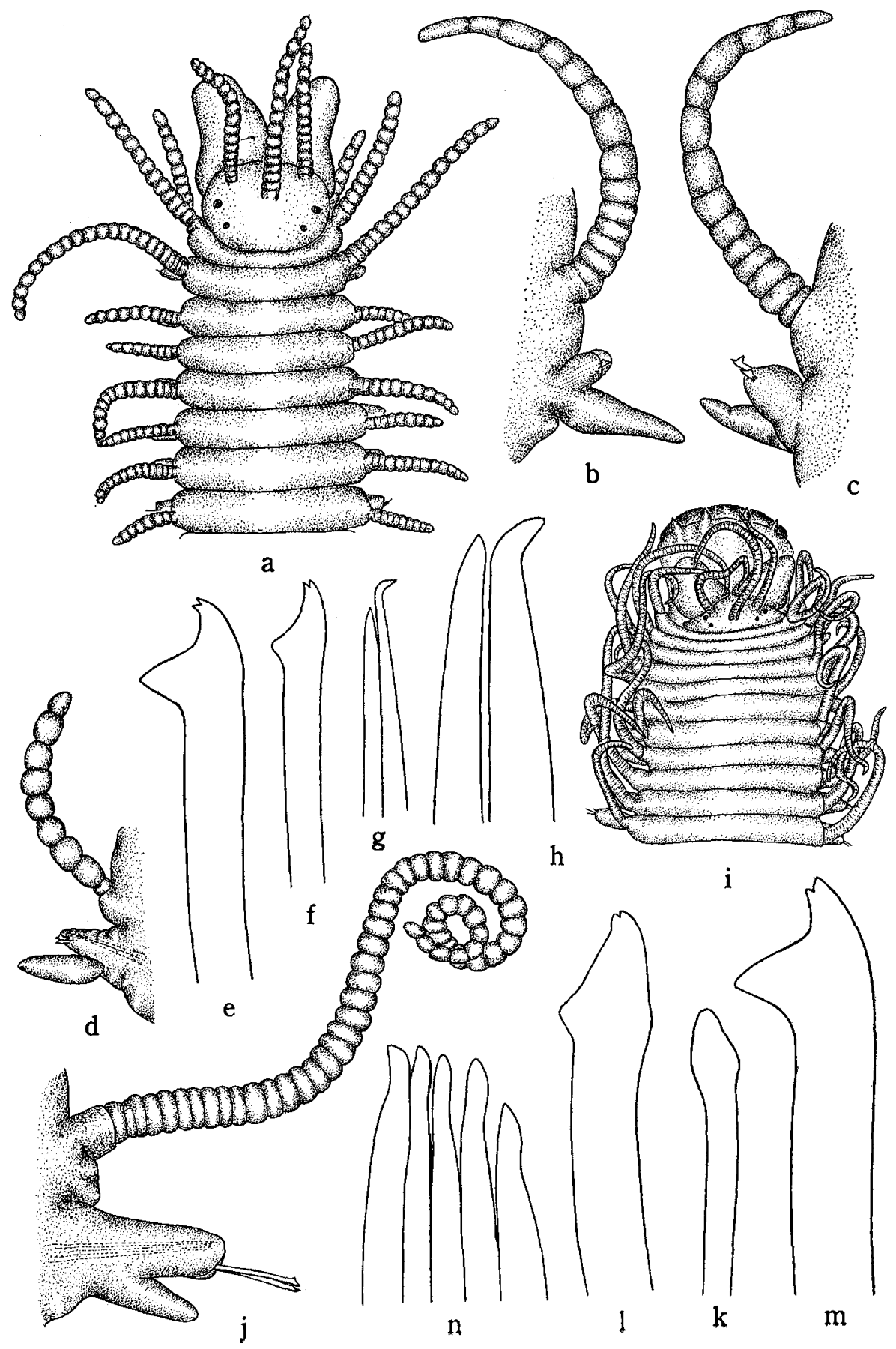
median antenna arises between the posterior eyes; it is about 3 times as long as the prostomium and consists of 39 articles. Lateral antennae arisc from the front of the anterior eyes and each has 26 to 28 articles. Palpi are subtriangular and completely separated. The pharynx is distally surrounded by 10 flesh papillae and has a chitinized tooth in its inner wall. The proventriculus extends through setigerous segment 15-24. Dorsal tentacular cirri are as long as the median antenna and ventral cirri are about two-thirds as long as the dorsal one. All dorsal cirri are slender and alternate long and short; each has more annulations than the stem, H. spongicola (GRUBE). The first cirrus has 48 instead of 32 articles, the third has 36 and the eleventh has 53 articles. On more posterior parapodia dorsal cirri alternate with 19 articles in short and 47 in long (fig. j) ones. Parapodia are subcylindrical and project laterally; each has two or three simple hooks. Setae of the first parapodium are slender and thick with blunt tip (fig. k). Posterior parapodia have thicker setae than those anterior, and each is distally bifid with a subdistal boss (figs. $1, \mathrm{~m}$ ). Ventral cirri are digitate and extend to the tips of the setigerous lobes. Acicula number 4 to 6 in a parapodium (fig. n).

The subspecies is new to Japan.

Distribution: France; Gulf of Naples; southern Japan.

Opisthosyllis LANGERHANS, 1879

\section{Type: Opisthosyllis brunnea LANGERHANS, 1879}

The body is large and papillate or smooth. The prostomium is broader than long and with or without an occipital flap arising from the tentacular segment. Antennae, tentacular and dorsal cirri are distinctly annulated. Palpi are long, subtriangular and fused at their bases. The pharynx is distally surrounded by soft papillae and the anterior margin is smooth. A middorsal tooth is present at a considerable distance from the anterior margin. Parapodia are conical lobes; each has a fascicle of uni- or bidentate compound setae, and sometimes also a few thick simple setae. Ventral cirri are digitate.

Key to species of Opisthosyllis from Japan

1. Dorsum covered with papillae; median parapodia with compound setae only. Opisthosyllis viridis

1. Dorsum without papillae; median parapodia with compound setae only or also thick simple setae. .2

Text-fig. 38. Haplosyllis spongicola (GRUBE). a, anterior end of specimen from Mukaishima, in dorsa] view, $\times 65$; b, 1st parapodium, in posterior view, $\times 85$; $\mathbf{c}$, median parapodium of individual from Usa, $\times 85 ; \mathrm{d}$, median parapodium of individual from Mukaishima, $\times 85$; e, simple seta from median parapodium, $\times 840$; $f$, simple seta from 1 st parapodium, $\times 840 ; \mathrm{g}$, acicula from same parapodium, $\times 840 ; \mathrm{h}$, acicula from median parapodium, $\times 840$.

Haplosyllis spongicola tentaculata (MARION). $\mathrm{i}$, anterior end, in dorsal view, $\times 25 ; \mathrm{j}$, 13 th parapodium with long dorsal cirrus, $\times 65 ; \mathrm{k}$, simple seta from 1 st parapodium, $\times 640 ; 1$, simple seta from 13 th parapodium, $\times 640 ; \mathrm{m}$, simple seta from 37 th parapodium, $\times 640 ; \mathrm{n}$, acicula from 13 th parapodium, $\times 640$. 
2. Parapodia with compound setae and thick simple seate; dorsal cirri in median region with 22 to 26

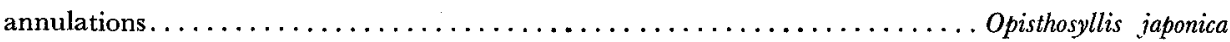

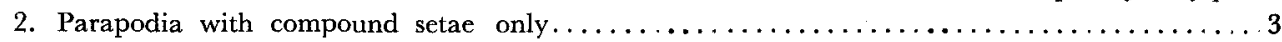

3. Compound setae in median region with bidentate appendages; anterior dorsal cirri with 45 to 100

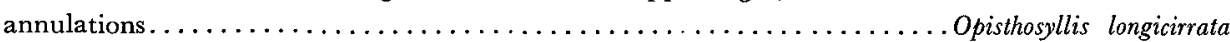

3. Compound setae in median region with unidentate appendages; anterior dorsal cirri with 17 to 34 annulations . Opisthosyllis brunnea

\section{Opisthosyllis viridis LANGERHANS, 1879}

(Text-fig. 39, a-o)

Obisthosyllis viridis LaNGerhans, 1879, p. 543, fig. 9.

Collection: Usa; Noto-ogi; Seto; Tamano; Mukaishima, in the intertidal zone. Description: The body measures 12 to $15 \mathrm{~mm}$ long and about $1 \mathrm{~mm}$ wide including parapodia, for 97 to 103 setigerous segments. The body is cream colored in a preserved specimen and has no color markings. The dorsum and cirrophore are closely covered with minute conical papillae (fig. a). The prostomium is subglobular and has two pairs of reddish eyes in trapezoidal arrangement (fig. b). Palpi are triangular and fused at their bases; they are slightly longer than the prostomium. A median antenna arises between the posterior eyes and has 20 annulations. Lateral antennae arise in front of the anterior eyes; each is about two-thirds as long as the median one. An occipital flap arises from the anterior margin of the first setigerous segment and covers the posterior part of the prostomium. The pharynx terminates in $10 \mathrm{soft}$ papillae and has a middorsal tooth at the level of the 14th or 15th setigerous segment. The proventriculus extends from setigerous segment 16-17 to 23-24. The first dorsal cirri are about twice as long as the lateral antennae; each has 33 to 37 annulations (fig. c). The second cirri are short, each with 20 to 23 annulations. Each of the fourth cirri (fig. d) has 30 to 33 and the fifth (fig. e) has 18 to 20 annulations. Farther back the dorsal cirri alternate long and short. In the median region the long dorsal cirri have 25, and the short 15 annulations (figs. $f, g$ ). Parapodia are conical lobes with distally slender tip. Setae are composite, with a subdistal accessory tooth; those of the anterior parapodia are slender and have long appendage with serrations on the cutting margin; appendages in superior are longer than those in inferior position (figs. h, i). Setae in the median and posterior parapodia are thick, have short falcate appendages with a minute accessory tooth and serrations along the cutting margin

Text-fig. 39. Opisthosyllis viridis LANGERhans. a, conical papillae of dorsum, $\times 370$; $\mathrm{b}$, anterior end, in dorsal view, $\times 35$; c, 1st parapodium, $\times 95$; $d$, 4th parapodium, $\times 95$; e, 5th parapodium, $\times 95$; f, median parapodium with long dorsal cirrus, $\times 95 ; \mathrm{g}$, short dorsal cirrus of median parapodium, $\times 95 ; \mathrm{h}$, superior compound seta from 1 st parapodium, $\times 950 ; \mathrm{i}$, inferior compound seta from same parapodium, $\times 950 ; \mathbf{j}$, compound seta from median parapodium, $\times 950 ; \mathrm{k}$, compound seta from posterior parapodium, $\times 950 ; 1$, superior simple seta from same parapodium, $\times 950 ; \mathrm{m}$, inferior simple seta from same parapodium, $\times 950 ; n$, acicula from 1 st parapodium, $\times 950$; 0 , aciculum from posterior parapodium, $\times 800$. 


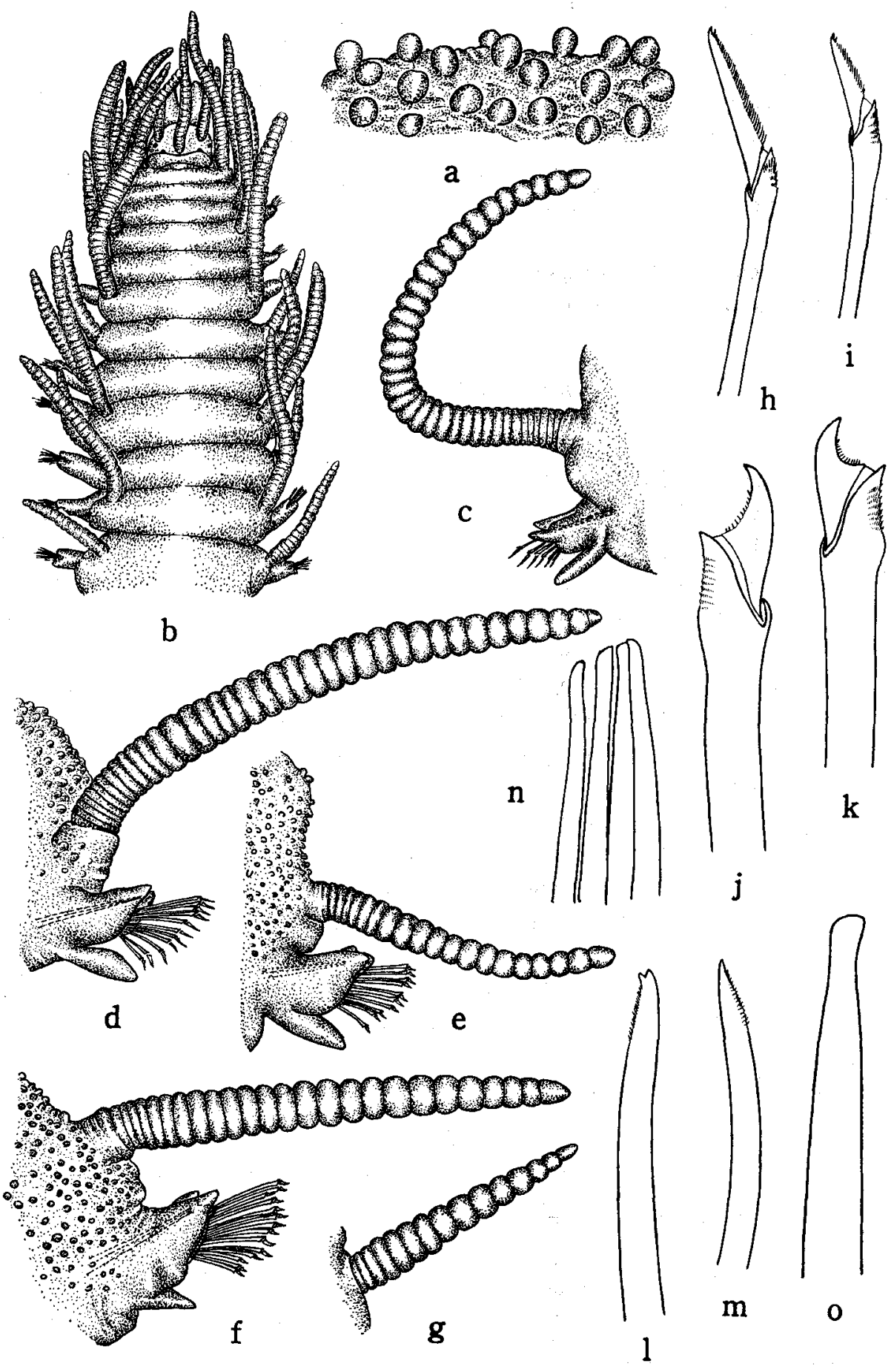


(figs. j, k). Each of the posterior parapodia has also two simple setae, one in superior, the other in inferior position. The superior one (fig. 1) is distally bidentate and emerges above the aciculum. The inferior one (fig. $\mathrm{m}$ ) terminates in an acute tip and is slightly curved. Both setae have minute serrations along one side. The ventral cirrus is short, digitate; that of an anterior parapodium reaches to the tip of the setigerous lobe. Acicula number 4 in an anterior (fig. $n$ ) and diminish to only one in a posterior setiger (fig. o); each ends in a round tip. The pygidium has two slender anal cirri.

The species is new to Japan.

Distribution: Madeira in Atlantic Ocean; southern Japan.

Opisthosyllis japonica n. sp.

(Text-fig. 40, a-p)

Collection: Mukaishima; Usa, Noto-ogi, from ascidians.

Description: The largest individual measures $40 \mathrm{~mm}$ long and $1.3 \mathrm{~mm}$ wide; it consists of 173 setigerous segments. The body is pale yellowish green in life and lacks color markings; its surface is smooth, without papillae on the dorsum or on parapodia. The prostomium is subglobular, wider than long; there are two pairs of reddish eyes in trapezoidal arrangement; anterior eyes are larger than the posterior ones (fig. a). Palpi are triangular and fused at their bases. An occipital flap arises from the anterior margin of the first setigerous segment, extends forward to partly conceal the prostomium; its anterior margin is slightly concave. A median antenna arises from the center of the prostomium and has about 50 annulations. Lateral antennae arise in front of the anterior eyes; each is about half as long as the median one; they have about 20 annulations. The pharynx has distally 12 to 14 fleshy papillae; there is no trepan. A middorsal pharyngeal tooth is located in setigerous segment 7 to 10 . The proventriculus extends from setiger 13 to 19 . Dorsal tentacular cirri are slightly shorter than the median antenna and ventral cirri are about half as long as the dorsal one. The first dorsal cirri are slender, each with 65 annulations. The second cirri are about one-third as long as the first one. Succeeding cirri alternate long and short, or with 44 annulations in the 15th and 25 in the 16th parapodium (figs. b, c). Thereafter they are reduced, those in median region are about half as

Text-fig. 40. Opisthosyllis japonica n. sp. a, anterior end, in dorsal view, $\times 30$; b, 15 th parapodium with long dorsal cirrus, in posterior view, $\times 65 ; \mathrm{c}, 16$ th parapodium with short dorsal cirrus, in same view, $\times 65$; d, median parapodium with long dorsal cirrus, $\times 65$; e, median parapodium with short dorsal cirrus, $\times 65 ; \mathrm{f}$, superior compound seta from 6 th parapodium, $\times 840 ; \mathrm{g}$, inferior compound seta from same parapodium, $\times 840 ; \mathrm{h}$, superior bidentate compound seta from 25 th parapodium, $\times 840 ; i$, median unidentate compound seta from same parapodium, $\times 840 ; j$, inferior unidentate compound seta from same parapodium, $\times 840 ; \mathrm{k}$, thick simple setae from median parapodium, $\times 420 ; 1$, unidentate compound seta from same parapodium, $\times 420 ; \mathrm{m}, \mathrm{n}$, superior and inferior compound setae from posterior parapodium, $\times 840$; 0 , inferior simple seta from same parapodium, $\times 840 ; \mathrm{p}$, acicula, $\times 640$. 


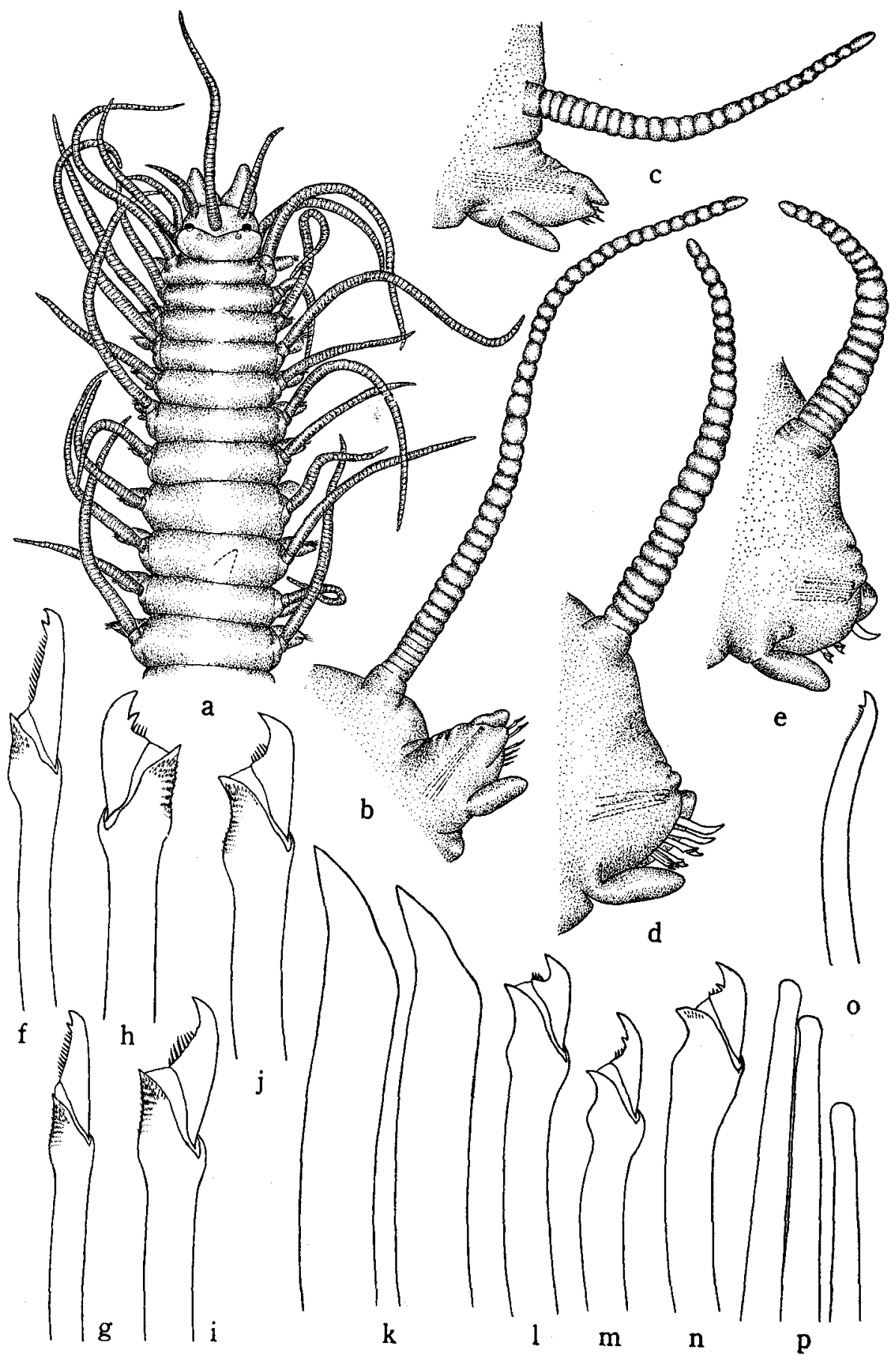


long as the body is wide; the longer have 26 and the shorter 22 articles (figs. d, e). Parapodia are conical with acute distal lobes. Anterior parapodia have bidentate composite setae; superior appendages (fig. f) are longer than inferior ones (fig. g); their cutting margins have long serrations. Farther back at the 25 th parapodium a fascicle consists of two kinds of setae; in superior position they are shortappendaged with a subdistal secondary tooth (fig. $h$ ) and in median and inferior positions they are unidentate (figs. $i, j$ ). Each median parapodium has a fascicle of one or two thick, distally bent simple setae (fig. $k$ ) and 3 to 4 compound setae with short unidentate appendage (fig. 1). Posterior parapodia have compound setae with a subdistal tooth (figs. $\mathrm{m}, \mathrm{n}$ ) and an additional, bidentate simple seta located at the inferior position; one side has minute serrations (fig. o). Acicula number six in a median parapodium; each has a round tip (fig. p). Ventral cirri are digitate and do not extend beyond the tips of parapodia. The pygidium has two slender anal cirri.

The species is characterized by the smooth body and median parapodia with compound setae with short unidentate appendage and one or two additional, thick simple setae.

Distribution: Central and southern Japan.

\section{Opisthosyllis sp.}

Opisthosyllis australis OKUDA, 1938, p. 91, fig. 11.

Opisthosyllis australis OKuda was reported from Susaki, Izu Peninsula. However, OKuDA did not describe the characters, but gave only figures. O. australis OkudA differs from O. australis Augener (1913, p. 218) from Sharks Bay of Australia. The latter has a papillated instead of smooth dorsum; setal fascicles have no particular, thick compound setae as OKunA's figures (fig. 11, c, d) and it has instead of lacks a medially concave, occipital flap.

Distribution: Central Japan.

\section{Opisthosyllis longicirrata MONRO, 1939}

(Text-fig. $41, a-j$ )

Opisthosylis longicirrata Monro, 1939, pp. 389-390, text-fig. 300; FAUveL, 1953, pp. 154-155, fig. 77, $\mathrm{f}-\mathrm{i}$.

Collection: Seto, in the intertidal zone.

Description: The larger of two anterior fragments measures $10 \mathrm{~mm}$ long and 1.7

Text-fig. 41. Opisthosyllis longicirrata Monro. a, anterior end, in dorsal view, $\times 20$; $b, 25$ th parapodium with long dorsal cirrus, $\times 45$; $c, 26$ th parapodium with short dorsal cirrus, $\times 45$; $d$, superior compound seta from 1st parapodium, $\times 740$; e, inferior compound seta from same parapodium, $\times 740$; $\mathrm{f}$, superior compound seta from 30 th parapodium, $\times 740 ; \mathrm{g}$, inferior compound seta from same parapodium, $\times 740 ; \mathrm{h}$, compound seta from posterior parapodium, $\times 740 ; i$, superior simple seta from same parapodium, $\times 740 ; j$, acicula from posterior parapodium, $\times 740$. 


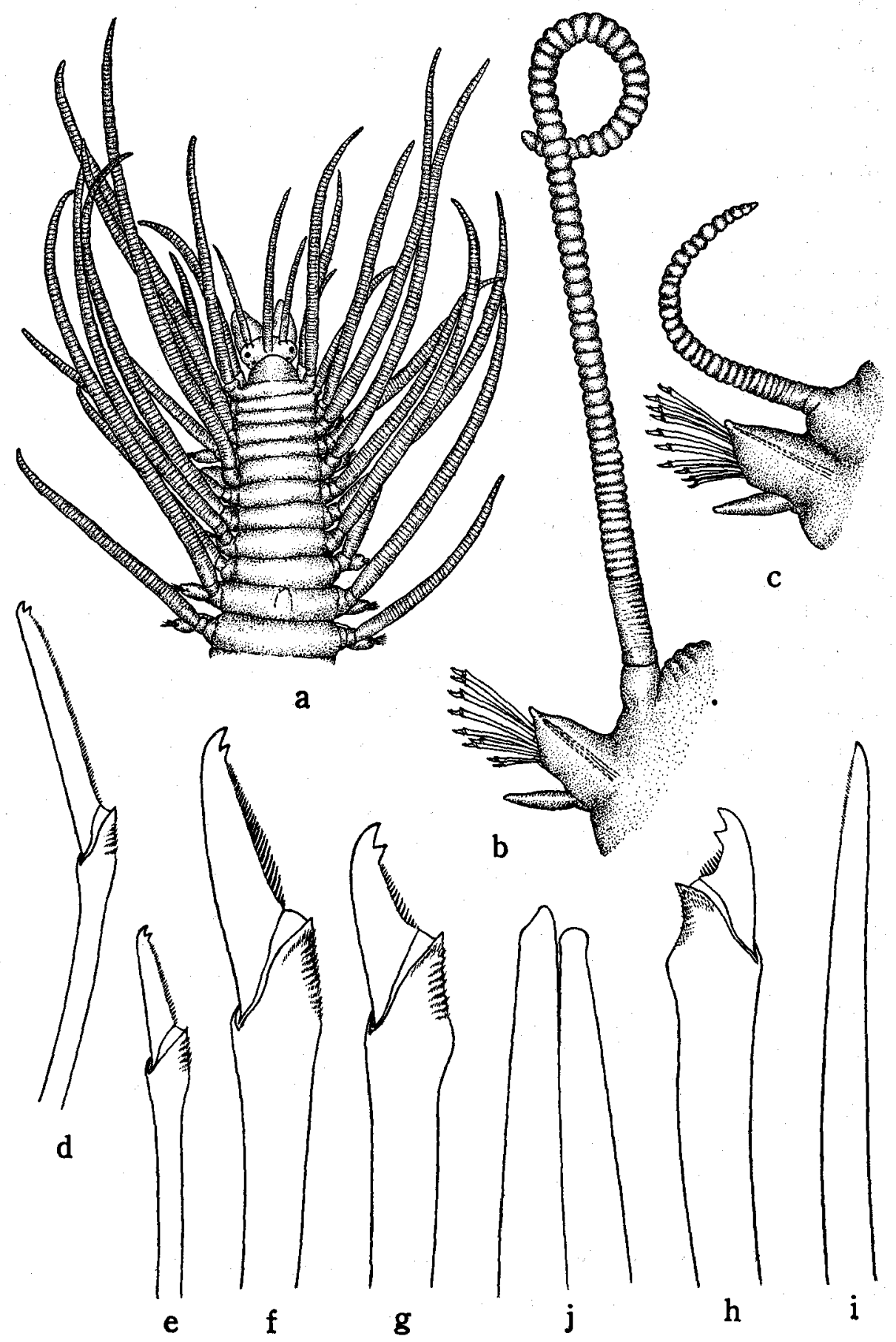


$\mathrm{mm}$ wide including parapodia; it consists of 68 setigerous segments. The body is creamy white in the preserved specimen and has no color markings; the dorsum is smooth. The prostomium is wider than long and has a pair of indistinct nuchal ridges along the posterior margin (fig. a). Two pairs of reddish eyes are in trapezoidal arrangement; the anterior eyes are the larger. Palpi are triangular lobes and longer than the prostomium; their bases are fused. A median antenna arises from the center of the prostomium and is three to four times as long as the prostomium; it consists of 40 annulations and a basally cylindrical part. Lateral antennae arise from anterior part of the prostomium; each is about two-thirds as long as the median antenna. A semicircular occipital flap arises from the tentacular segment and covers the posterior half of the prostomium. The pharynx is distally surrounded by a circlet of ten fleshy papillae; a middorsal tooth occurs at the level of the llth setigerous segment. The dorsal tentacular cirri are about twice as long as the lateral antennae; each has about 50 annulations and a cylindrical base. The ventral tentacular cirri are about half as long as the dorsal one. The first dorsal cirri are longer than the dorsal tentacular cirri; each consists of about 70 annulations and an indistinctly annulated base. The second ones are slightly longer than half as long as the first one. The third ones are as long as the first ones. The fourth, sixth, eighth and ninth ones are long, each with 90 to 100 annulations; the fifth and seventh dorsal cirri are about two-thirds as long, each with 45 to 55 annulations. The following cirri alternate long and short (figs. b, c). In the median region long dorsal cirri are about three times as long as the short ones. Parapodia are conical with distally pointed tip; each has a fascicle of bidentate compound setae. In the first parapodium seate are slenderer than those of more posterior parapodia and the appendages in the superior seate are longer than those of inferior ones; these have small serrations along the cutting margin (figs. d, e). Setae of more posterior parapodia are thicker than those in front and have longer serrations along the cutting margins (figs. $f, g$ ). The posterior or 68th segment has short appendaged composite setae (fig. h), and a superior simple seta present; one side is minutely serrated (fig. i). Acicula number four in anterior parapodia and gradually reduced to only two (fig. j) or one. Ventral cirri are digitate and extend to the tip of the setigerous lobe.

The species is characterized as follows: (1) the body is smooth; (2) dorsal cirri alternate long and short, and have 30 to 100 annulations, and (3) the setae are bidentate composite.

The species is new to Japan.

Distribution: Tahiti; Maldive Archipelago; Red Sea; southern Japan.

Opisthosyllis brunnea LANGERHANS, 1879

(Text-fig. 42, a-n)

Opisthosyllis brunnea LANGERHANS, 1879, pp. 541-543, fig. 7. 
Collection: Kutsugata, in Rishiri Island, in the intertidal zone.

Description: The largest specimen measures $19 \mathrm{~mm}$ long and $1 \mathrm{~mm}$ wide including parapodia; it consists of 68 setigerous segments. The body is yellowish white and has no color markings, preserved. The prostomium is subgloblar and broader than long (fig. a). Two pairs of reddish eyes are in trapezoidal arrangement and the anterior is larger than the posterior pair. A median antenna arises between the posterior eyes and is about four times as long as the prostomium; it has 23 annulations: Lateral antennae emerge from the anterior margin of the prostomium; each is about half as long as the median one. Palpi are subtriangular and longer than the prostomium; they are fused at their bases only. The posterior part of the prostomium is covered by an occipital flap. The pharynx is distally surrounded by 10 soft papillae and has a middorsal tooth (fig. b) at the level of the 4th or 5th setigerous segments. The space between the anterior margin and the middorsal tooth is about 3 times the length of the tooth; the inner wall of the pharynx is reddish purple. The proventriculus extends from setigerous segment 10 to 15 . The dorsal tentacular cirri are as long as the median antenna and the ventral cirri are about half as long as the dorsal one. The first dorsal cirri are about twice as long as the dorsal tentacular cirri; each has 32 to 34 annulations. The second cirri are about half as long as the first ones. Farther back the dorsal cirri alternate in length; those in median parapodia are long, with 30 to 34 annulations (fig. c) and short, with 23 to 28 (fig. d); the long cirri are as long as the body is wide. Parapodia are oblong; they have a fascicle of compound setae emerging from between the two lobes; each seta has a short appendage. Setae in anterior parapodia are slenderer than those farther back and their short appendages have an accessory tooth (fig. e); their cutting margins have coarse serrations. The appendages of median parapodia are unidentate with coarse serrations along the cutting margin (fig. f). Those in posterior parapodia are of two kinds and occur in equal number; unidentate (fig. g) or with an accessory tooth (fig. h). In addition, posterior parapodia (fig. i) have two simple setae, one in superior and one in inferior position; the superior one (fig. $j$ ) is distally bifid with minute serrations along one side, and the inferior one (fig. k) has a small, subdistal secondary tooth; the distal convex part has minute serrations. Acicula number 4 in anterior parapodia and decrease to only one posteriorly (fig. 1). Ventral cirri are digitate and do not extend beyond the tips of setigerous lobes. The pygidium has two slender anal cirri.

The posterior half of the body in most specimens has newly formed short antennae and eyes. The eyes begin from the 13 th setigerous segment of the stock; they number 2 to 6 pairs, are located on each segment or every other segment or at irregular intervals.

In a single individual two short antennae and two pairs of reddish eyes arise from the lateral sides of anterior part of the 34th setigerous segment. Two short posterior regions, each consisting of 2 or 3 setigers and a pygidium arise newly from the posterior part of the next segment (figs. $m, n$ ). Each dorso-lateral side of the next 

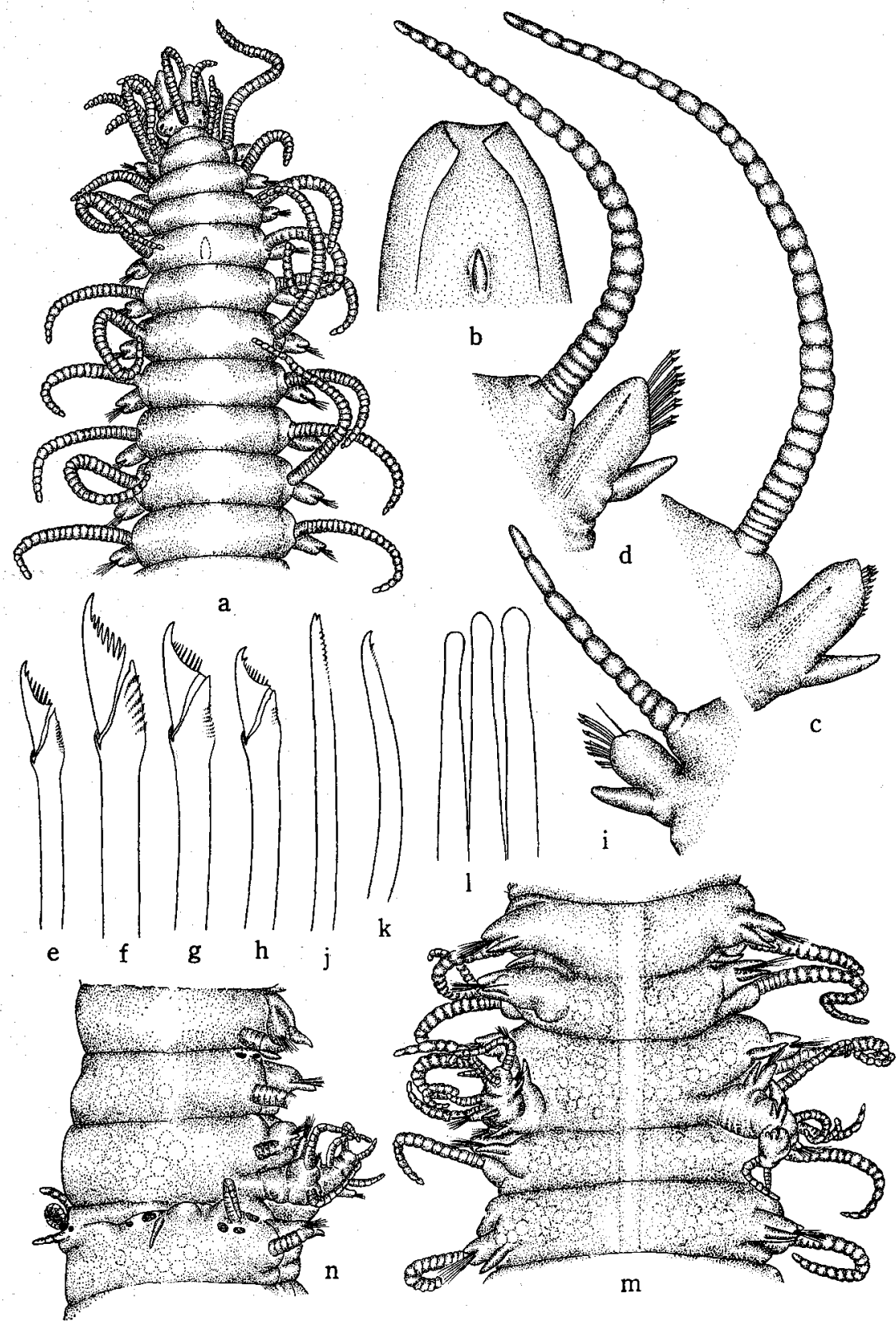
segment has two groups of eyes 2 or 3 in a group, and a short antenna arises from each group of eyes. The body cavity is filled with ova.

Specimens from Japan agree with the description of Opisthosyllis brunnea LANGERHANs from Madeira except in the number of pharyngeal papillae.

The species is new to Japan.

Distribution: Madeira; northern Japan.

\section{Geminosyllis new genus}

\section{Type: Geminosyllis ohma (IMA JIMA and HARTMAN, 1964)}

The body is subcylindrical; segments are moderately long. The prostomium is pentagonal and has no median cleft; eyes two pairs. A median antenna arises between the posterior eyes. Palpi are very large, broadly triangular and completely separated. The pharynx has a trepan with 10 teeth and a large, middorsal one; its outer lining terminates in 10 soft papillae. All antennae and dorsal cirri are slender and articulated. Setae number 3 to 7 in a fascicle; all are simple, subdistally thickend and distally bifid; a simple seta occurs in posterior parapodia.

Geminosyllis resembles Haplosyllis LANGERHANs in that (1) the body is subcylindrical and (2) all parapodia have simple setae only. Geminosyllis differs from Haplosyllis in that it has a trepan with 10 teeth instead of lacks one.

Geminosyllis is also allied to Trypanosyllis (Trypanosyllis); both have a trepan with 10 teeth and a middorsal tooth in its inner wall. The first differs from the second in the following respects; (1) the body is subcylindrical instead of dorso-ventrally depressed; (2) palpi are very large, broadly triangular, about as long as the prostomium, instead of small, conical and sometimes not visible in dorsal view.

Trypanosyllis (Trypanoseta) Imajima and Hartman (1964, p. 129) is referred to Geminosyllis because the body differs in these respects from Trypanosyllis, except in its trepan.

\section{Geminosyllis ohma (IMAjIma and Hartman, 1964), new combination}

(Text-fig. 43, a-g)

Trypanosyllis (Trypanoseta) ohma Imajma and Hartman, 1964, pp. 129-130, pl, 31, figs. a-d. Syllis (Haplosyllis) spongicola Uschakov, 1955, p. 179, fig. 50, A.

Text-fig. 42. Opisthosyllis brunnea LANGERHANs. a, anterior end, in dorsal view, $\times 25$; $b$, distal part of inner wall of pharynx opened by dissection, $\times 42$; $c$, median parapodium with long dorsal cirrus, in anterior view, $\times 57$; d, median parapodium with short dorsal cirrus, in anterior view, $\times 57$; $\mathrm{e}$, compound seta from anterior parapodium, $\times 720 ; \mathrm{f}$, compound seta from median parapodium, $\times 720 ; \mathrm{g}$, unidentate compound seta from posterior parapodium, $\times 720 ; \mathrm{h}$, compound seta with an accessory tooth from same parapodium, $\times 720 ; \mathrm{i}$, posterior parapodium, $\times 72$; $\mathrm{j}$, superior simple seta from posterior parapodium, $\times 720 ; \mathrm{k}$, inferior simple seta from same parapodium, $\times 720 ; 1$, acicula, $\times 720 ; \mathrm{m}$, a part of body showing newly formed two pygidiums, in ventral view, $\times 27 ; \mathrm{n}$, same, in dorsolateral view, $\times 27$. 

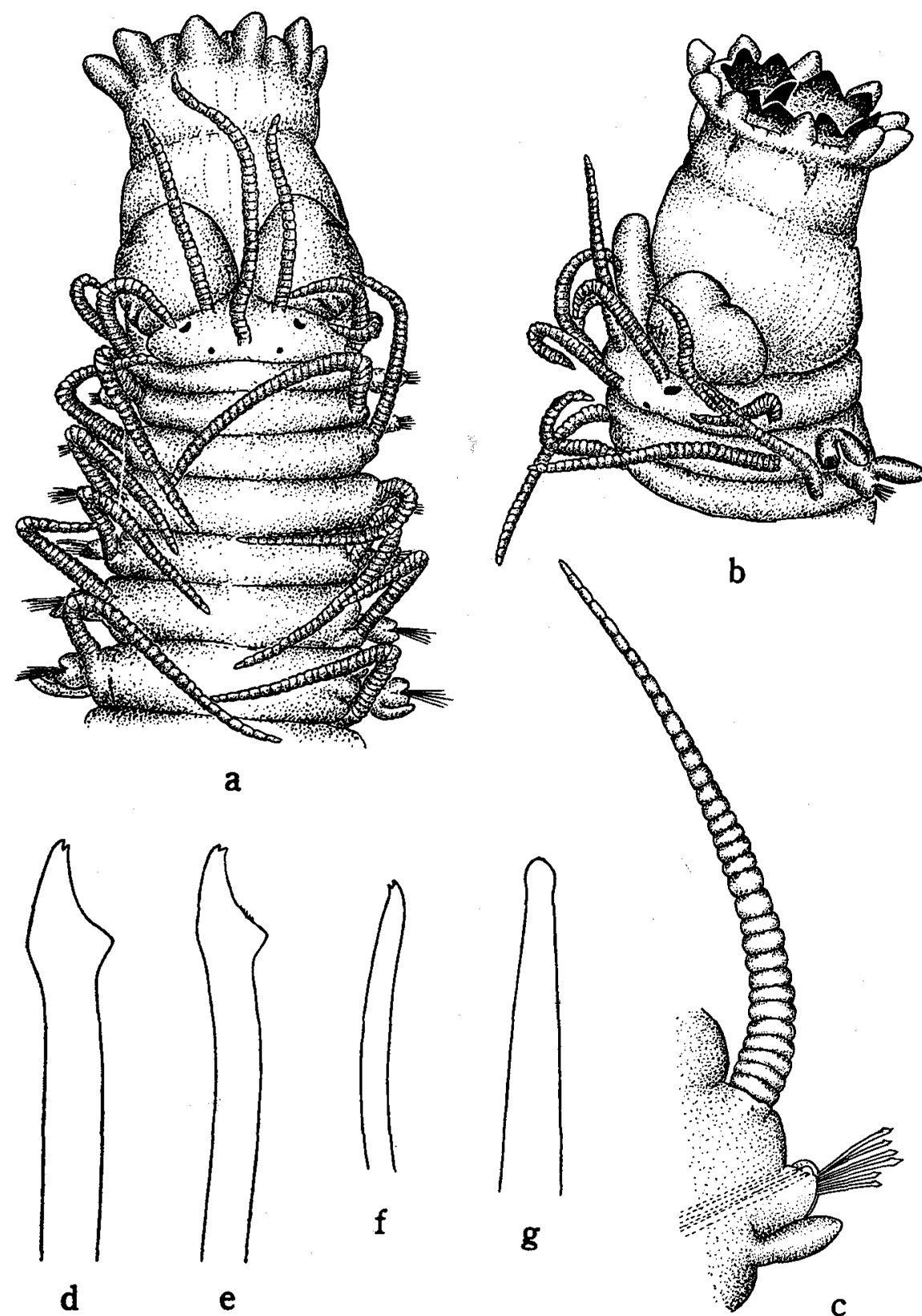

d

e

C

Text-fig. 43. Geminosyllis ohma (Imajima and Hartman). a, anterior end with everted proboscis, in dorsal view, $\times 30 ; \mathrm{b}$, anterior end showing pharyngeal teeth, in dorsolateral view, $\times 30 ; \mathrm{c}$, 18th parapodium, $\times 45$; d, bifid simple seta with smooth cutting margin from anterior parapodium, $\times 950$; e, bifid simple seta with minute serrations along the cutting margin from same parapodium, $\times 950$; , inferior simple seta from posterior parapodium, $\times 950$; g, aciculum from posterior parapodium, $\times 950$. 
Occurrence: Shirikishinai, from the littoral zone, and from $120 \mathrm{~m}$.

Diagnosis: The largest specimen measures $32 \mathrm{~mm}$ long and $2 \mathrm{~mm}$ wide including parapodia; it consists of 82 setigerous segments. The body is subcylindrical, pale yellow and has no color markings. The prostomium is depressed pentagonal and lacks a median cleft (fig. a). Two pairs of eyes are reddish, the anterior pair is reniform and larger than the posterior eyes. A mediar antenna has 30 annulations; it is inserted between the posterior circular eyes. Each of the lateral antennae has 25 annulations; they are inserted at the anterior margin of the prostonium. Palpi are conspicuously large, thick and broadly triangular. The protruded pharynx is long and cylindrical, distally surrounded by 10 soft papillae; the trepan has 10 triangular teeth and a sharp, subterminal middorsal one (fig. b). The chitinized lining is dark brown. The proventriculus extends from segment 12 to 21 . Dorsal tentacular cirri are about as long as the lateral antennae, and the ventral is about half as long as the dorsal one. Dorsal cirri in the anterior region of the body alternate between long, with 35, and short with 30 articles (fig. c). Those in the median region are about equally long, with 35 articles. Parapodia are short and have uniform, simple setae numbering 6 or 7 in a fascicle. The seta is distally bifid and subdistally thickened; the cutting margin is smooth (fig. d) or has minute serrations (fig. e). A posterior parapodium has setae similar to those in more anterior parapodia. In addition, the last few parapodia have a distally bifurcate, simple seta (fig. f) in inferior position. Acicula number four in median parapodia and gradually decrease to occur singly posteriorly (fig. g); each has a rounded tip. Ventral cirri are digitate and slightly longer than the setigerous lobe. The pygidium has long anal cirri.

Through the courtesy of Dr. P. V. Usanakov one complete specimen of Syllis (Haplosyllis) spongicola Uschakov (1955) from the Kurile Islands was examined. It measures $25 \mathrm{~mm}$ long and $1.5 \mathrm{~mm}$ wide for 85 setigerous segments. The body is dorsally arched and ventrally flattened. The pharynx is reddish brown, and has a trepan consisting of 10 triangular teeth in the anterior margin and a middorsal tooth. It is similar to Haplosyllis spongicola in the forms of its simple setae, but it has a trepan instead of lacks. It is here referred to Geminosyllis ohma.

Distribution: Northern Japan; Kurile Islands.

\section{Trypanosyllis ClaPARÈDE, 1864}

The body is long and usually depressed; segments are numerous and short. The prostomium is rectangular or quadrate; eyes number two pairs; palpi are separated from each other. The pharynx has a trepan with usually 10 teeth in the terminal circlet, and with or without a subdistal, middorsal tooth in its inner dorsal wall. Dorsal cirri are long or short and closely articulated. Setae are simple or composite, with unidentate or bidentate tips. Reproduction is by posterior budding, in linear or collateral series. 
Species of Trypanosyllis from Japan are clearly separable into two groups, based on the characters of the pharyngeal trepan: ( 1 ) this has 10 teeth and a middorsal one, or (2) it has 10 teeth without a middorsal one. The latter group is again separable; parapodia have either compound or simple setae. Based on these characters three subgenera were established by Imajima and Hartman (1964).

Key to subgenera of Trypanosyllis from Japan

1. Pharynx with a trepan of 10 distal teeth and a middorsal tooth.............. Trypanosyllis

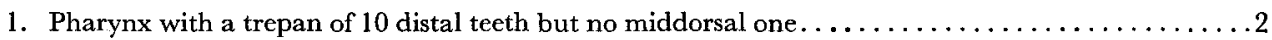

2. Parapodia with compound setae only $\ldots \ldots \ldots \ldots \ldots \ldots \ldots \ldots \ldots \ldots \ldots \ldots \ldots \ldots \ldots \ldots \ldots \ldots \ldots$ Trypanta

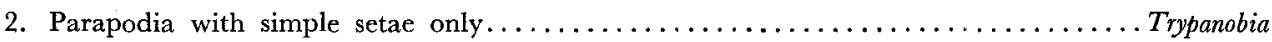

\section{Trypanosyllis (Trypanosyllis) Ima Jima and HaRTMan, 1964}

\section{Type: $T .(T$.$) zebra (GRUBE, 1860)$}

The body is long, vermiform and broadly depressed; segments are numerous and very short. The prostomium is rectangular; eyes number two pairs; palpi are separated to the base. The pharynx has a trepan with usually 10 distal teeth and a large, subdistal middorsal tooth in its inner dorsal wall; the trepan is usually surrounded by a fleshy membrane terminating in 10 soft papillae. Dorsal cirri are long or short and closely articulated. Setae are of several kinds, most are composite and falcigerous; their tips bidentate or unidentate; posterior ones may be simple. Reproduction is by posterior budding, resulting in individuals called Tetraglene.

\section{Trypanosyllis (Trypanosyllis) coeliaca nipponica IMAJIMA and HARTMAN, 1964}

Trypanosyllis (Trypanosyllis) coeliaca Claparède, nipponica Imajtma and Hartman, 1964, pp. 124-125 pl. 29, fig. j; pl. 30, figs. a-e.

Occurrence: Off Shirikishinai, from $80-180 \mathrm{~m}$, in a sponge.

Diagnosis: The largest specimen measures $17 \mathrm{~mm}$ long and $2.2 \mathrm{~mm}$ wide and consists of 140 setigerous segments. The body is pale yellow, without markings and very broadly depressed. The prostomium is rectangular without a conspicuous median cleft. The two pairs of eyes are large, with the anterior somewhat the larger. The palpi are conical and separated from each other. Median and lateral antennae arise from the anterior margin of the prostomium; they are thick and short, with 10 to 12 distinct articulations. The pharynx terminates in 10 soft papillae; the trepan has 10 teeth and a middorsal one; its chitinized wall is thin and pale. The proventriculus is short, extending through segment 13 to 19. Dorsal cirri are thick, short and have 8 to 14 annulations. Each parapodium has three kinds of setae: (1) bidentate compound setae with serrations along the cutting margin are located in the 
superior part of the fascicles; (2) unidentate compound setae with hooked ends, and (3) compound setae with a small accessory tooth are in middle and inferior parts of the fascicle; these have a shaft with minute serrations along one side. Acicula occur single or double; each terminate in a pointed tip. Each of the last few posterior parapodia has a simple seta with a subdistal tooth in inferior part of the fascicle. The pygidium is provided with a pair of short anal cirri.

Distribution: Northern Japan.

\section{Trypanosyllis (Trypanedenta) Imajima and Hartman, 1964}

\section{Type : T. (Trypanedenta) gemmipara JoHnson, 1901}

The body is broadly depressed; segments are much wider than long. The prostomium is subquadrate, consisting of two lobes separated by a median cleft. Eyes number two pairs; palpi are separated from each other to the base. The pharynx has a trepan with 10 teeth; a middorsal, subterminal tooth is absent. Dorsal cirri are thick and articulated. Setae are of a single kind, composite falcigers, and terminate in a bifid or entire tip. Reproduction is by budding in which the stock gives rise to clustered stolons called Tetraglene.

Key to species of Trypanosyllis (Trypanedenta) from Japan

1. Anterior dorsum with two transverse stripes on each segment; parapodia in median region of the body with two kinds of compound setae.......... Trypanosyllis (Trypanedenta) taeniaformis

1. Anterior dorsum without color markings; parapodia in median region of the body with a single kind of compound setae................... Trypanosyllis (Trypanedenta) gemmipara

\section{Trypanosyllis (Trypanedenta) gemmipara JoHNSON, 1901}

(Text-fig. 44, a-m)

Trypanosyllis gemmipara JoHnson, 1901, p. 405, pl. 7, figs. 72-76.

Trypanosyllis misakiensis IzuKa, 1906, p. 283, figs. 1-4; 1912, p. 185, pl. 20, figs. 2-6; Fauvel, 1932, p. 80; 1953, pp. 158-159; Uschakov, 1955, p. 183, fig. 52a-d (a part).

Trypanosyllis (Trypanedenta) gemmipara Imajima and Hartman, 1964, p. 126, pl. 30, figs. f, g.

Collection: Shirikishinai, from the littoral zone to depths of $120 \mathrm{~m}$; Tokoro, in $30 \mathrm{~m}$; Seto, in littoral zone.

Description: The largest individual measures $61 \mathrm{~mm}$ long and $4 \mathrm{~mm}$ wide including parapodia; it consists of 385 setigerous segments. The body is broad, flat and the middorsal region is somewhat convex; there are no color markings. The prostomium is subquadrate; the two lobes are separated by a postmedian cleft (fig. a). Two pairs of eyes are reddish; the anterior pair is the larger. Three antennae arise from the anterior margin of the prostomium; a median one is about 3.5 times as long as the prostomium and consists of 30 to 34 articles; lateral ones are about two-thirds 


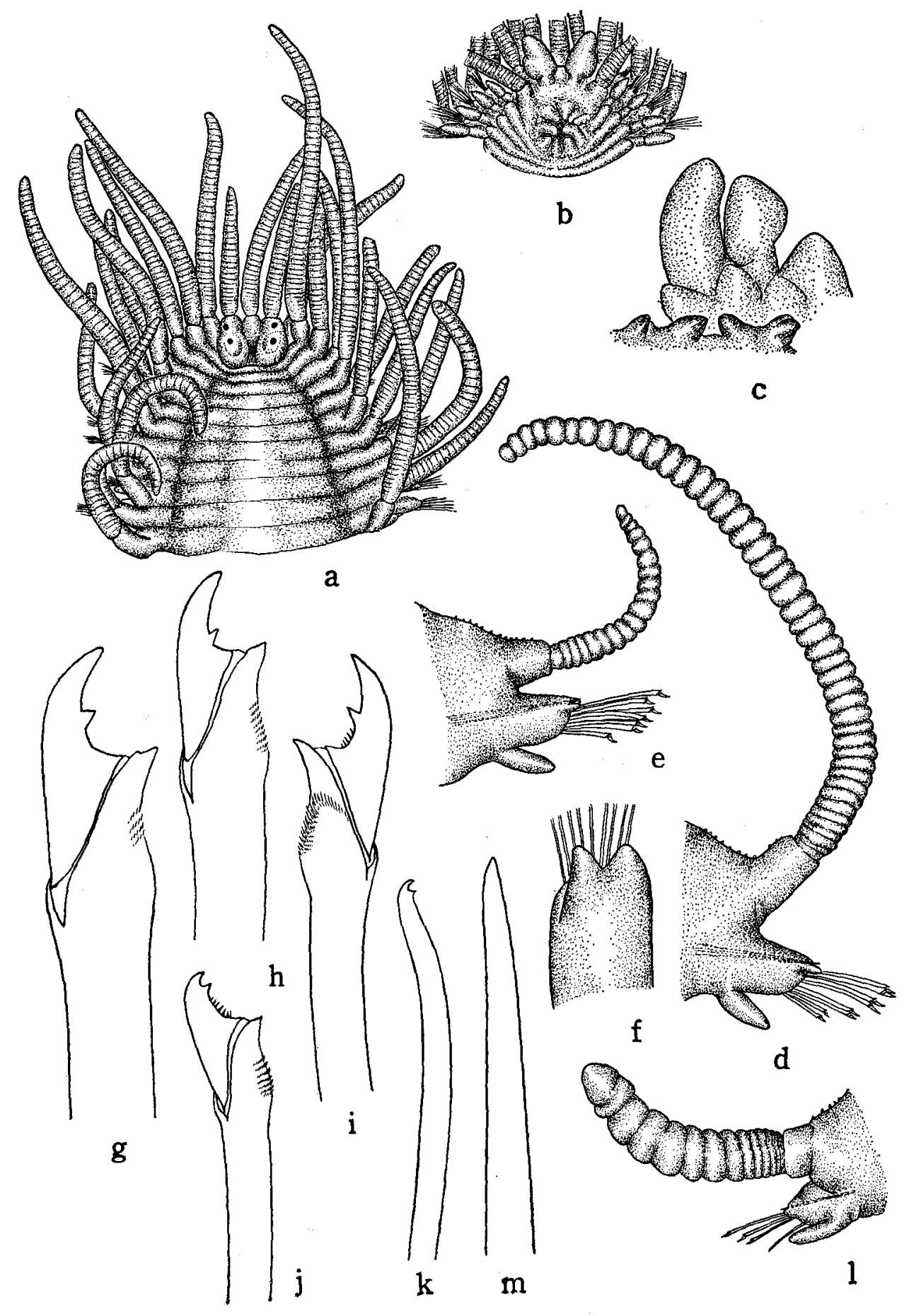


as long as the median one. Palpi are short lobes with peduncles and completely separated; they are about as long as the prostomium (fig. b). The pharynx is thick, about half as long as the body is wide; it is distally surrounded by 8 to 11 soft papillae. The inner chitinized wall of the pharynx is yellow and thin. The trepan has 8 to 11 teeth; these are pale brown and indistinct (fig. c); there is no middorsal tooth. The proventriculus extends from segment 22 to 25 , or from 38 to 45 . Dorsal cirri are thick and alternate long and short; those of median region have 45 in long (fig. d) and 19 articles in short (fig. e) cirri. Parapodia are subcylindrical and terminate distally in two superior lobes (fig. f). Setae are compound falcigers; those in median parapodia are distally falcate and have a conspicuous secondary tooth nearly midway between the tip and base of the appendage (figs. $g, h$ ). The cutting margins of the setae are smooth in large individuals and minutely serrated in young ones (fig. i). The posterior compound setae have a secondary tooth near the distal tip and the cutting margin has minute serrations (fig. $j$ ). In addition, a simple bifid seta with fine serrations along one side of the shaft (fig. k) occurs in the inferior part of the fascicle (fig. 1). Acicula are straight and number five to one in posterior segments (fig. m). Sexual reproduction occurs in Hokkaido from May to September as collateral budding from posterior segments.

Distribution: Washington; western Canada; Alaska to Mexico; Indian Ocean; north-west coast of Japan Sea; Kurile Island; northern to southern Japan.

\section{Trypanosyllis (Trypanedenta) taeniaformis (HASWELL, 1886)}

(Text-fig. 45, a-i)

Syllis taeniaformis Haswell, 1886, p. 9, pI. 50, figs. 4,5.

Trypanosyllis richardi Gravier, 1900, p. 168, pl. 9, figs. 12, 13, textfigs. 3941.

Trypanosyllis taeniaformis AUGENER, 1913, p. 230.

Trypanosyllis zebra FAUveL, 1934, p. 311; OkUdA, 1937, p. 272, figs. 13, 14.

Trypanosyllis (Trypanedenta) taeniaformis Imajima and Hartman, 1964, pp. 127-128, pl. 30, figs. h-k.

Collection: Funadomari, in Rebun Island; Matsumae; Moheji; Ishizaki; Shirikishinai, in shallow water from laminarian holdfasts and in depths to $120 \mathrm{~m}$; off Shiriyazaki, in $150 \mathrm{~m}$; Asamushi; Onagawa; Misaki; Sugashima; Seto; Tamano; Mukaishima; Usa; Noto-ogi; Ariake Sea, in $10 \mathrm{~m}$.

Description: The largest specimen measures $47 \mathrm{~mm}$ long and $2.5 \mathrm{~mm}$ wide; it

Text-fig. 44. Trypanosyllis (Trypanedenta) gemmipara Johnson. a, anterior end, in dorsal view, $\times 20$; $\mathrm{b}$, anterior end showing palpi, in ventral view, $\times 20 ; \mathrm{c}$, a part of pharynx opened by dissection, $\times 80$; $d$, median parapodium with long dorsal cirrus, $\times 35$; e, median parapodium with short dorsal cirrus, $\times 35$; $\mathrm{f}$, distal part of parapodium, in dorsal view, $\times 95$; g, superior compound seta from median parapodium, $\times 480 ; \mathrm{h}$, inferior compound seta from same parapodium, $\times 480 ; \mathrm{i}$, compound seta from median parapodium in young individual, $\times 480 ; \mathrm{j}$, compound seta from posterior parapodium, $\times 950 ; \mathrm{k}$, inferior simple seta from same parapodium, $\times 950 ; 1$, posterior parapodium, $\times 80 ; \mathrm{m}$, aciculum, $\times 800$. 


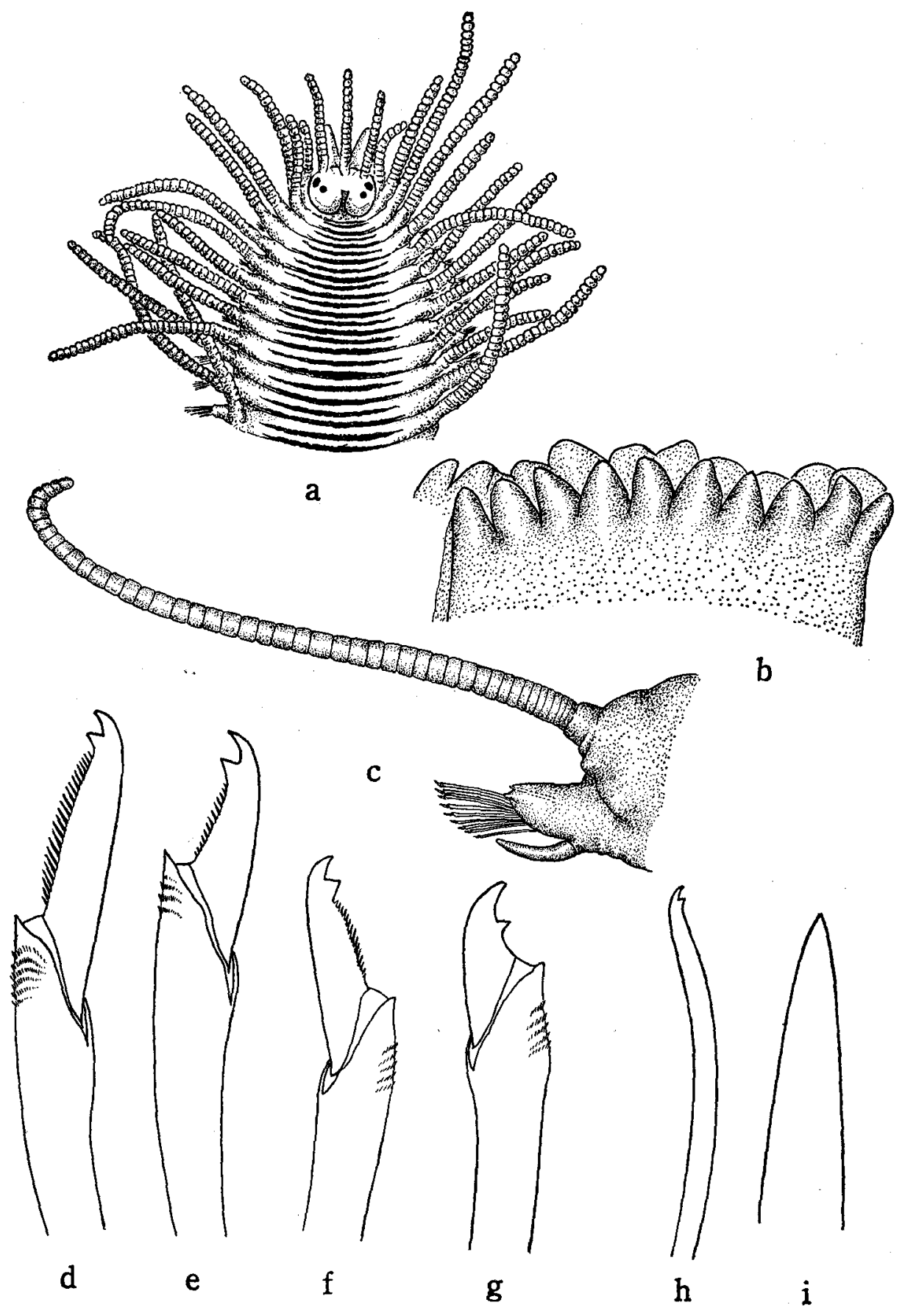


consists of 255 setigerous segments. The body is broadly depressed and a middorsal region is somewhat convex. Each segment has two purple, narrow transverse bands; they are distinct in preserved specimen (fig. a). These bands gradually become indistinct in the posterior region of the body. The prostomium is suboval and has a deep cleft extending from the posterior margin forward to the center of the lobe. Two pairs of eyes are reddish, and the anterior eyes are the larger and wider apart. Palpi are slender and completely separated; they are about as long as the prostomium. All prostomial antennae arise from nearly same level of the prostomium. A median antenna has 30 to 46 annulations and each of the lateral ones has 25 to 38 annulations. The pharynx (fig. b) is thick and distally surrounded by 10 soft papillae. The trepan has 10 reddish brown, chitinized teeth; there is no subterminal, middorsal tooth. The proventriculus extends from segment $16-18$ to 26-34. Dorsal cirri are reddish purple and alternate long and short, with annulations numbering 46 and 30 in the middle region (fig. c). Parapodia are conical and provided with fascicles of bidentate compound setae. The setae of anterior parapodia are of a single kind; the setal appendages in superior position are longer than the inferior ones and have serrations on the cutting margin (figs. d, e). The median and posterior parapodia have two kinds of compound setae; the superior setal appendages (fig. f) are similar to those of anterior setae; those in inferior position are shorter than the superior ones, with a smooth cutting margin (fig. g). In addition, posterior fascicles have an inferior bidentate simple seta (fig. h). Ventral cirri are digitate. Acicula occur double; each is a blunt, thick, distally tapering rod (fig. i).

The species is similar to Trypanosyllis zebra in its dorsal color pattern. T. zebra (Fauvel, 1934, p. 311) from Misaki and Seto were re-examined. The pharynx has a trepan of 10 teeth and no subterminal, middorsal tooth. These features agree with the present species.

Distribution: Southeastern Australia; Red Sea; Persian Gulf; Palau Islands; Japan.

\section{Trypanosyllis (Trypanobia) IMAJIMA and HARTMAn, 1964}

\section{Type: T. (Trypanobia) asterobia OKADA, 1933}

The body is depressed; the dorsum lacks a zebra-striped pattern. The prostomium is quadrate; palpi are greatly reduced and not visible in dorsal view. The pharynx has a trepan with 10 teeth and lacks a subterminal middorsal one. Dorsal

Text-fig. 45. Trypanosyllis (Trypanedenta) taeniaformis (HAswelL). a, anterior end, in dorsal view, $\times 15$; $b$, distal end of pharynx opened by dissection, $\times 80 ; c$, median parapodium with long dorsal cirrus, $\times 35$; $d$, superior compound seta from anterior parapodium, $\times 800$; e, inferior compound seta from same parapodium, $\times 800$; f, superior compound seta from median parapodium, $\times 720 ; \mathrm{g}$, inferior compound seta from same parapodium, $\times 720$; h,inferior simple seta from posterior parapodium, $\times 950 ; i$, aciculum, $\times 720$. 
cirri have a long cirrophore. Setae are simple, not composite and distally unidentate. Asexual reproduction is by linear chainlike budding.

Key to species of Trypanosyllis (Trypanobia) from Japan

1. Parapodia with one kind of simple furcate setae........ Trypanosyllis (Trypanobia) depressa

1. Parapodia with three kinds of simple setae, falcate with boss or spur, and simple hook......... Trypanosyllis (Trypanobia) asterobia

\section{Trypanosyllis (Trypanobia) depressa (Augener, 1913), new combination}

(Text-fig. 46, a-f)

Haplosyllis depressa Augener, 1913, pp. 216-217, pl. 3, figs. 29, 30, textfig. 27 a, b.

Collection: Ishizaki, near Hakodate, in 8 to $13 \mathrm{~m}$.

Description: A complete individual measures $16 \mathrm{~mm}$ long and $2.7 \mathrm{~mm}$ wide including parapodia; it consists of 132 setigerous segments. The body is flat, and the middorsum is slightly convex. The dorsum is yellowish brown and has a blackish transverse band at intervals of four or five segments. The prostomium is subglobular and divided into two ocular lobes by a median cleft arising from the posterior margin (fig. a). There are two pairs of reddish eyes; the anterior eyes are the larger. The hind part of the prostomium is covered by the first setigerous segment. A median antenna arises between the anterior eyes and has 10 annulations. Lateral antennae arise from the anterior margin of the prostomium and are slightly shorter than the median one. Palpi are small globular lobes and separated from each other. The pharynx is distally surrounded by 10 soft papillae; the trepan (fig. b) has 10 teeth; it lacks middorsal tooth; its chitinized wall is thin and pale. The proventriculus extends from setigerous semgent 14 to 21 . Dorsal cirri are short, about one-third as long as the body is wide; in a median region they alternate between long with 12 (fig. c) and short with 7 articles (fig. d). Parapodia are blunt cylindrical and have two conspicuous acicular lobes. Setae are of one kind; they are simple, unequally bifurcate (fig. e). Ventral cirri are digitate, about as long as the setigerous lobe. Acicula number four in median parapodium; each is distally bent (fig. f).

The species is characterized as follows: (1) the body is flattened; (2) the pharynx has a trepan but no middorsal tooth and (3) setae are simple and distally bifurcated.

Through the courtesy of the Zoologisches Staatsinstitut und Zoologisches Museum one specimen of Holotype of Haplosyllis depressa Augener (1913)from Sharks Bay was examined. Its body is flat. The prostomium is subglobular and has a decp cleft extending from the posterior margin forward to the center of the lobe. The pharynx, examined by dissection, has a trepan with 10 triangular teeth; a middorsal subterminal tooth is absent. Setae are simple, not composite. Haplosyllis depressa Augener has these characteristics and is here referred to Trypanosyllis (Trypanobia) Imajima and HARTMAN, 1964.

Distribution: Sharks Bay, Australia; northern Japan. 

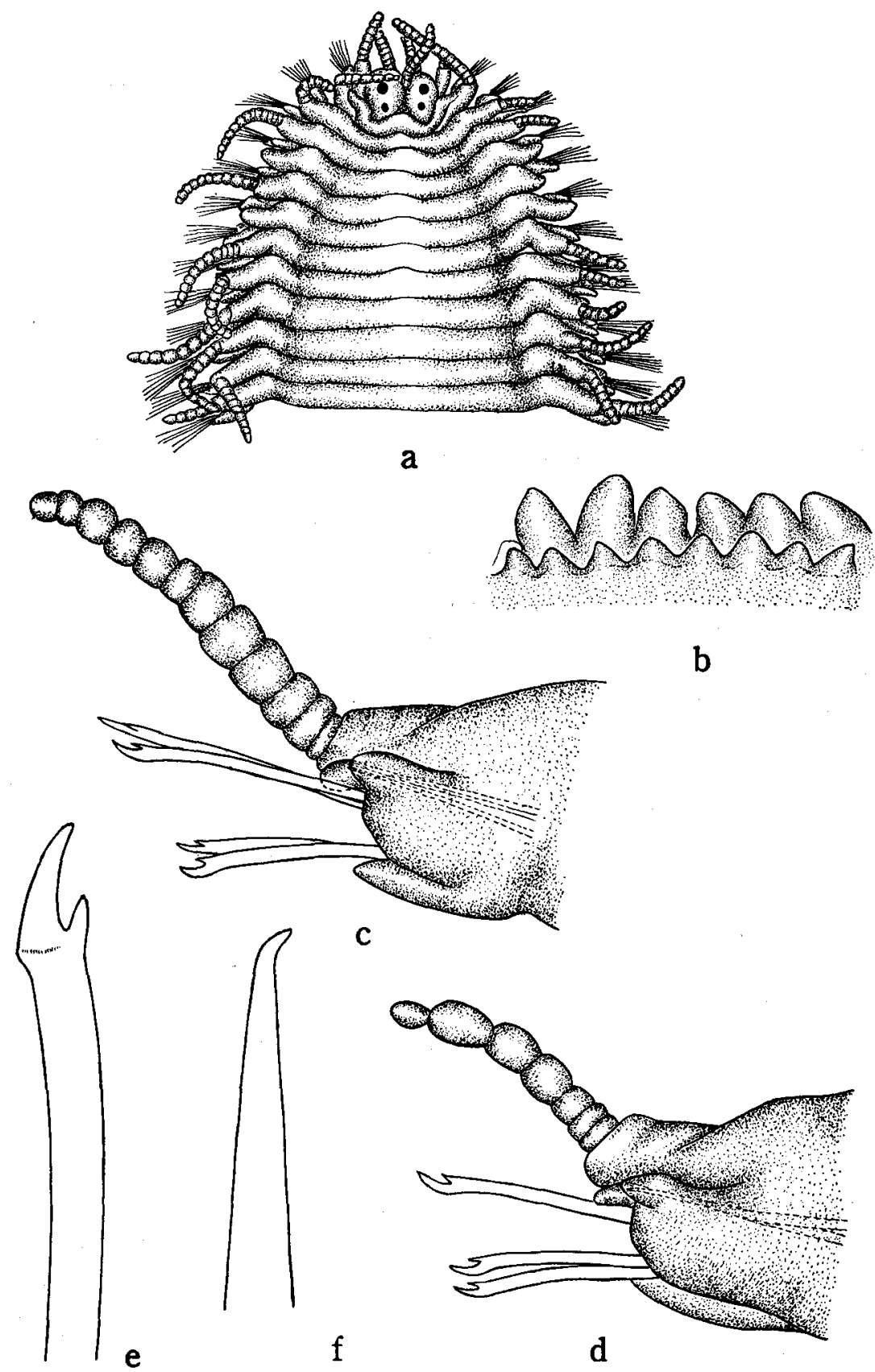

Text-fig. 46. Trypanosyllis (Trypanobia) depressa (AUgener). a, anterior end, in dorsal view, $\times 32$; b, a part of pharynx opened by dissection, $\times 95$; $\mathrm{c}$, median parapodium with long dorsal cirrus, in anterior view, $\times 95$; d, median parapodium with short dorsal cirrus, in same view, $\times 95$; e, furcate simple seta, $\times 370 ; \mathrm{f}$, aciculum, $\times 740$. 


\title{
Trypanosyllis (Trypanobia) asterobia OKADA, 1933
}

\author{
(Text-fig. 47, a-h)
}

Trypanosyllis asterobia OKaDA, 1933, pp. 325-332, pl. 12, figs. 1-4, textfigs. 1-5.

Trypanosyllis (Trypanobia) asterobia Imajima and Hartman, 1964, p. 128.

Occurrence: Misaki, associated with an asteroid, Iuidia quinaria von MARTENs; Ariake Sea, in 8 to 20 meters.

Description: The body measures 80 to $120 \mathrm{~mm}$ long and $3 \mathrm{~mm}$ wide excluding dorsal cirri and setae; it consists of 350 to 420 segments. Segments are pale yellow or cream-colored and lack transverse stripes. The prostomium is quadrate, with a slight cleft on the posterior margin; there are two pairs of eyes (fig. a). A median antenna arises between the posterior eyes, it has 10 to 11 annulations. Lateral antennae arise from the anterior margin of the prostomium; each has 6 to 7 annulations. Palpi are small liplike elevations separated from each other. The pharynx is distally surrounded by 10 soft papillae and the trepan has 10 reddish brown chitinized teeth; there is no middorsal tooth. The proventriculus extends from setigerous segment 8 to 12. Dorsal cirri have a distinct cirrophore and the styles alternate long and short in the median region (fig. b); they have 20 articles in short and 30 in long ones. Parapodia are subconical and each has a fascicle of 3 to 5 simple setae. Setae in anterior and median parapodia are distally falcate and have a subterminal boss on one side (figs. $c$, d). Setae in the posterior parapodia are of three kinds; superiormost are distally falcate ones with a subterminal spur (fig. e), median ones are falcate with a subterminal spur and minute serrations along the cutting margin (fig. f), and inferior setae are distally bent and simple (fig. g). Ventral cirri are digitate and do not extend beyond the tips of the setigerous lobe. Acicula number four in a median parapodium; each terminates distally in a blunt tip (fig. h).

Asexual reproduction is chainlike; it was detailed by Orada (1933).

Distribution: Southern Japan.

\section{Syllis Savigny, 1818}

\section{Type: Syllis monilaris SAVIGNy, 1818}

The body is long and slender and consists of many segments. The prostomium is subglobular, with two pairs of eyes and three antennae. Antenna, tentacular cirri and dorsal cirri are distinctly articulated. The pharynx is distally surrounded by soft papillae and the anterior margin of the inner wall is smooth, with a middorsal tooth. Parapodia are small, conical and have setae with short or long appendages, pseudocompound setae, or simple setae. Ventral cirri are short and digitiform.

Syllis may be distinguished from Typosyllis LANGERHANs for having pseudocompound or simple setae in addition to compound setae. 


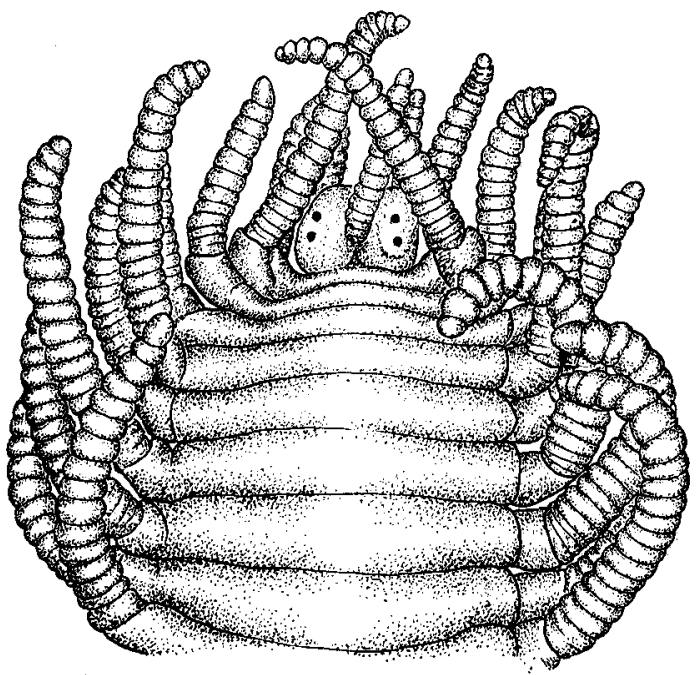

a

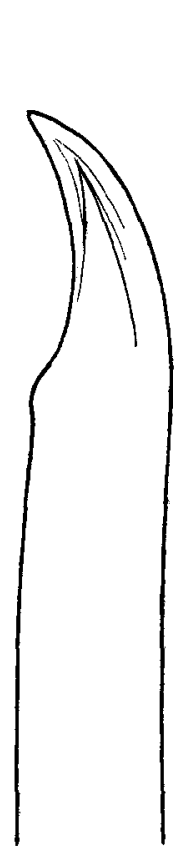

C

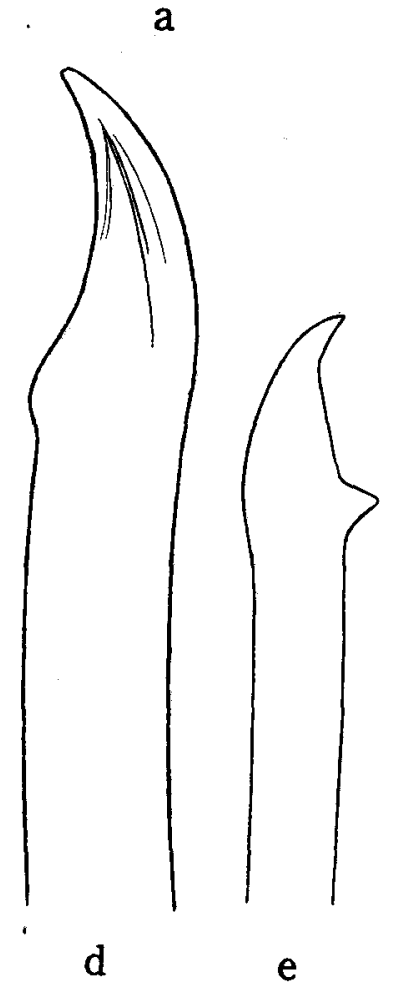

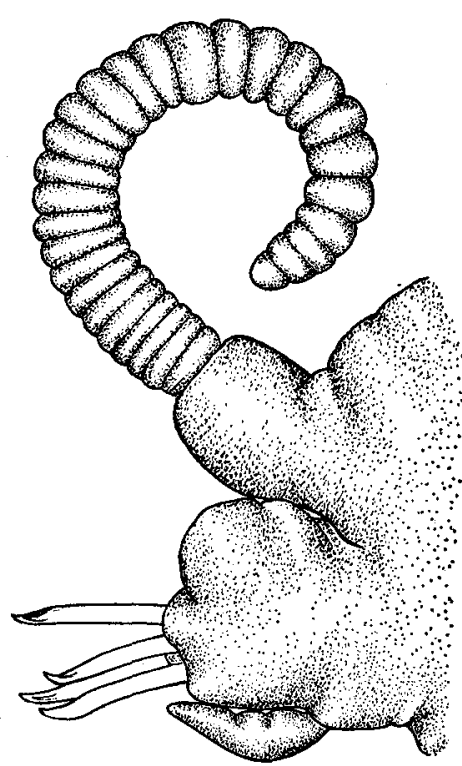

b

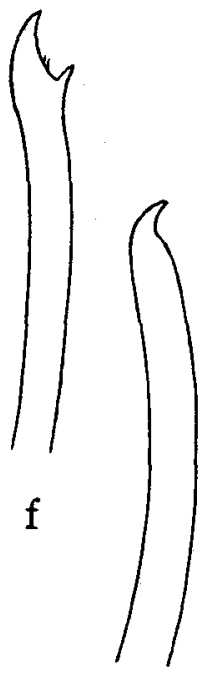

g

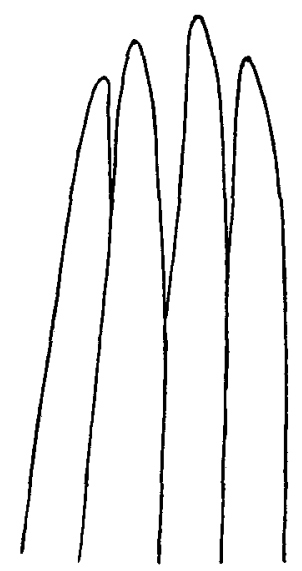

h

Text-fig. 47. Trypanosyllis (Trypanobia) asterobia OxAdA. a, anterior end, in dorsal view, $\times 35$; b, median parapodium, in posterior view, $\times 55 ; \mathrm{c}, \mathrm{d}$, simple setae from median parapodium, $\times 370$; e, superior falcate simple seta with subterminal spur from posterior parapodium, $\times 950$; f, median falcate simple seta with subterminal spur and minute serrations from same parapodium, $\times 950 ; \mathrm{g}$, inferior simple seta from same parapodium, $\times 950 ; \mathrm{h}$, acicula from median parapodium, $\times 950$. 
Key to species of Syllis from Japan

1. Body much branched, resulting from lateral and posterior budding.......... Syllis ramosa

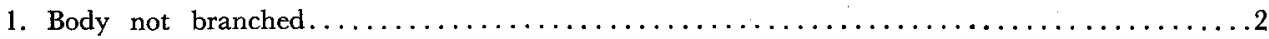

2. Parapodial setae bidentate compound, or pseudocompound with short appendage, or simple setae; median dorsal cirri with 35 to 45 annulations.................. Syllis spongiphila

2. Parapodial setae bidentate compound with long and short appendages, and additional thick simple setae in a median region; median dorsal cirri with fewer than 30 annulations .............

3. Median dorsal cirri with 6 to 7 annulations; with bifurcated simple setae in median parapodia....

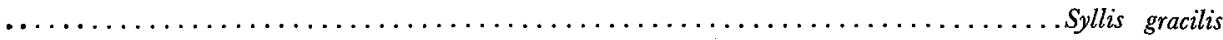

3. Median dorsal cirri with 20 to 28 annulations; with a simple, thick seta and compound setae in median parapodia. Syllis amica

\section{Syllis amica QuATREFAGES, 1865}

$$
\text { (Text-fig. 48, a-o) }
$$

Syllis amica F Fuvel, 1923, pp. 258-259, fig. 95, e-n; Cognetti, 1957, p. 14.

Syllis (Syllis) amica Rullier, 1964, pp. 158-159.

Collection: Asamushi; Sugashima; Seto; Tamano; Mukaishima; Usa, in the intertidal zone.

Description: The largest specimen measures $30 \mathrm{~mm}$ long and $1 \mathrm{~mm}$ wide including parapodia; it consists of 170 setigerous segments. The prostomium is subglobular and wider than long; it has two pairs of reddish eyes in trapezoidal arrangement (fig. a); the anterior pair is the larger. Palpi are subtriangular and slightly shorter than the prostomium; they are fused at their bases. A median antenna arises between the posterior eyes; it is about four times as long as the prostomium and has 28 annulations. Lateral ones arise from the anterolateral margin of the prostomium; each has 20 annulations and is about two-thirds as long as the median one. The pharynx is distally surrounded by 10 soft papillae, the inner membrane has a large, subdistal tooth (fig. b). The proventriculus extends from setigerous segment 12 to 18 . The tentacular segment is reduced dorsally; it has two pairs of tentacular cirri. Each of the dorsal tentacular cirri has 25 annulations and is slightly shorter than the median antenna; the ventral ones are about half as long as the dorsal one. The first dorsal cirri are longer than the following ones and each has 36 annulations (fig. c). The second cirri are about half as long as the first one. On more posterior segments the dorsal cirri alternate in length. In a median region the long

Text-fig. 48. Syllis amica QuAtrefages. a, anterior end, in dorsal view, $\times 32$; $b$, distal part of pharynx opened by dissection, $\times 85 ; \mathrm{c}, 1$ st parapodium, in posterior view, $\times 85$; d, median parapodium with long dorsal cirrus, in anterior view, $\times 85$; e, median parapodium with short dorsal cirrus, in same view, $\times 85 ; \mathrm{f}$, superior compound seta from 1 st parapodium, $\times 840 ; \mathrm{g}$, inferior compound seta from same parapodium, $\times 840$; h, superior thick simple seta from median parapodium, $\times 840$; $\mathrm{i}$, compound seta from same parapodium, $\times 840 ; \mathrm{j}$, superior compound seta from posterior parapodium, $\times 840 ; \mathrm{k}$, inferior compound seta from same parapodium, $\times 840 ; 1$, superior simple seta from same parapodium, $\times 840 ; \mathrm{m}$, inferior simple seta from same parapodium, $\times 840 ; \mathrm{n}$, acicula from 1st parapodium, $\times 840 ; 0$, aciculum from posterior parapodium, $\times 840$. 

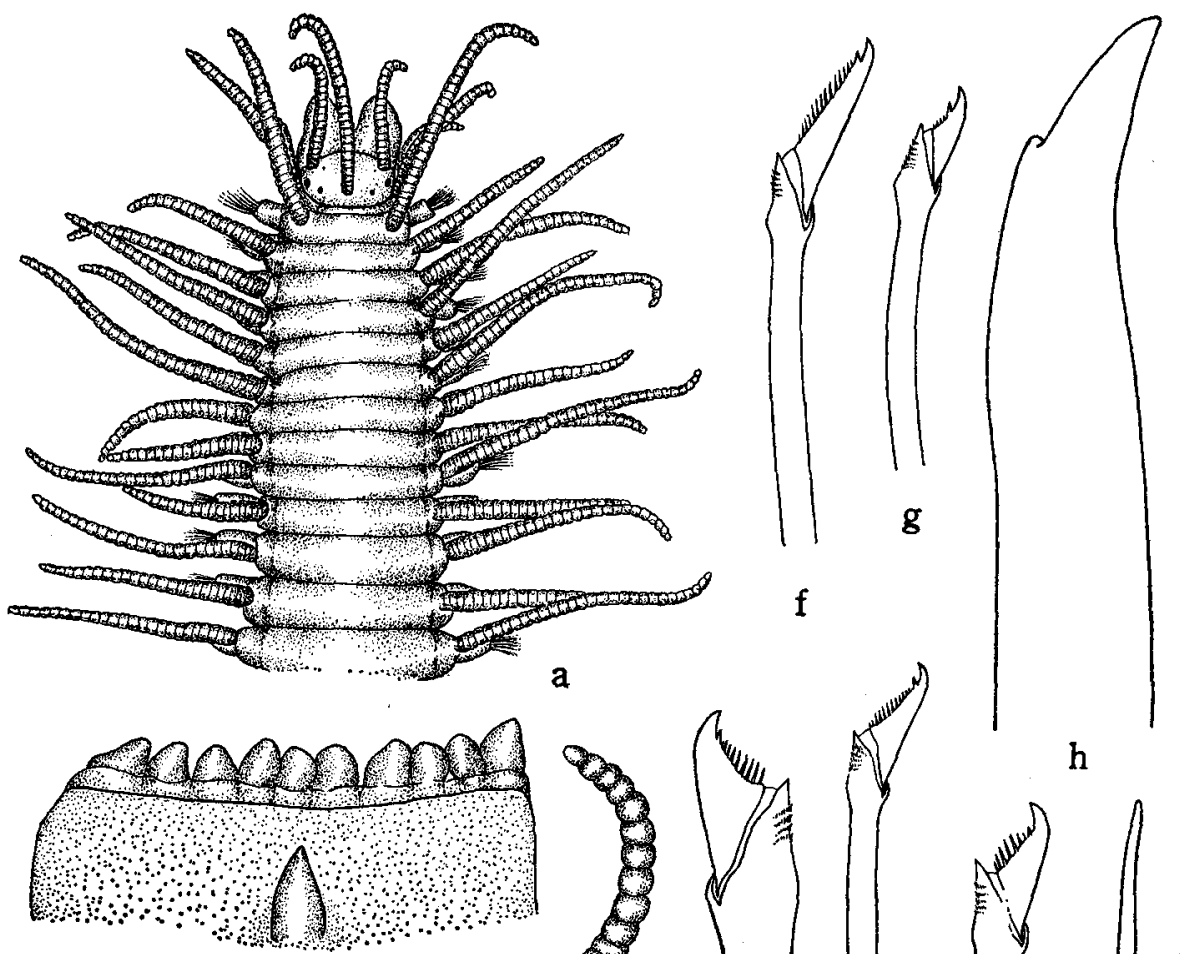

a
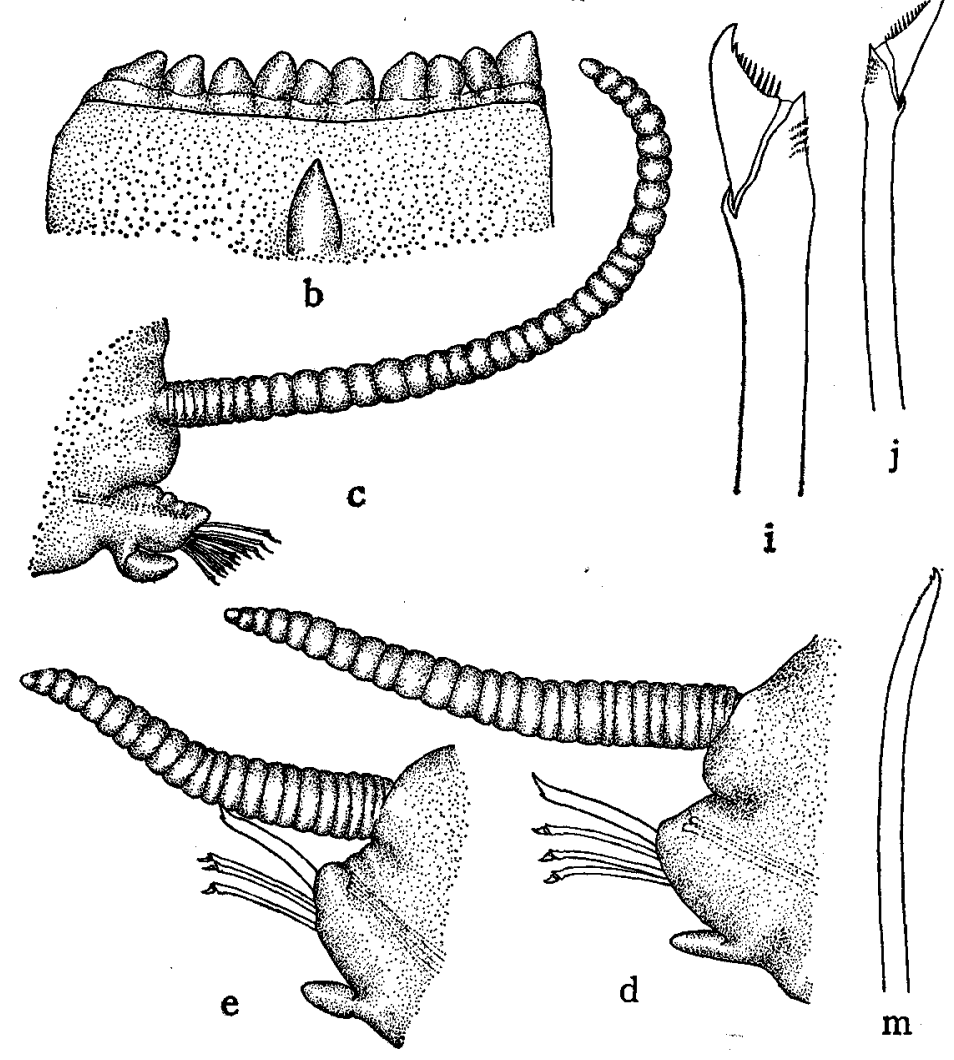

h
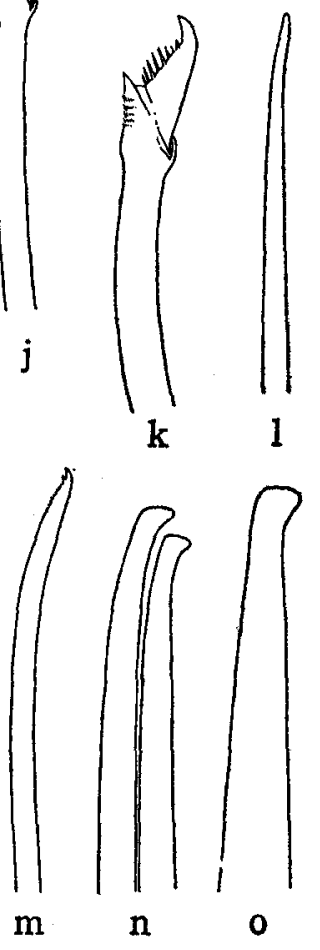
cirri are as long as the body is wide; each has 26 to 28 annulations (fig. d), and the short cirri are about two-thirds as long as the long ones and each has 20 to 23 annulations (fig. e); all are basally thickest. A normal parapodium is bluntly conical and has a fascicle of compound setae. Setae in the first parapodium number about 10 in a fascicle and the setal appendages in the superior part of the fascicle are longer than inferior ones; each appendage has a subdistal secondary tooth and long serrations along the cutting margin (figs. f.g). From about the 20th parapodium the appendage of the more superior seta falls from the shaft which becomes gradually thicker posteriorly; it is about twice as thick as the other compound setae. In a median parapodium the setae consist of one superior simple seta (fig. h) and three compound setae with short appendages (fig. i). Posterior parapodia have a fascicle of slender bidentate compound setae (figs. $\mathrm{j}, \mathrm{k}$ ) similar to the first falcigers and two simple setae; the superior one just above the aciculum has an entire tip (fig. 1), and the inferior one is distally bifid and has minute serrations on one side (fig. $\mathrm{m}$ ). Acicula number 1 to 3 in parapodia; they are distally curved with blunt tip (figs. $\mathrm{n}, \mathrm{o}$ ). The pygidium has two long anal cirri.

Japanese specimens were compared with two from France, identifid by QUATREFAGES (1868); they correspond in all details.

The species is new to Japan.

Distribution: France; Atlantic Ocean; Mediterannean Sea; Japan.

\section{Syllis gracilis GRUBE, 1840}

(Text-fig. 49, a-k)

Syllis gracilis Fauvel, 1923, p. 259, fig. 96, f-i; Pettibone, 1963, pp. 116-118, fig. 32.

Syllis (Syllis) gracilis FauveL, 1953, pp. 147-148, fig. 73, f-i.

Collection: Amakusa, in intertidal zone; Uraga Strait, in 20 to $40 \mathrm{~m}$; Ariake Sea, in $20 \mathrm{~m}$.

Description: The largest specimen measures $10 \mathrm{~mm}$ long and $0.8 \mathrm{~mm}$ wide including parapodia; it consists of 91 setigerous segments. The dorsum of the anterior body has two brown transverse bands on each segment (fig. a). The prostomium is subglobular and has two pairs of reddish eyes in trapezoidal arrangement. A

Text-fig. 49. Syllis gracilis Grube. a, anterior end, in dorsal view, $\times 50 ; \mathrm{b}, 4$ th parapodium, $\times 100$; c, median parapodium, $\times 100 ; d$, compound seta from 4 th parapodium, $\times 840 ; \mathrm{e}, \mathrm{f}, \mathrm{g}$, bifurcate simple setae from median parapodium, $\times 420 ; \mathrm{h}$, compound seta from posterior parapodium, $\times 840$; i, superior simple seta from same parapodium, $\times 840 ; \mathrm{j}$, inferior simple seta from same parapodium, $\times 840 ; \mathrm{k}$, acicula from anterior parapodium, $\times 840$.

Syllis spongiphila Verrill. 1, anterior end, in dorsal view, $\times 50 ; \mathrm{m}, 21$ st parapodium with long dorsal cirrus, $\times 85 ; \mathrm{n}$, short dorsal cirrus from 22nd parapodium, $\times 85 ; 0$, compound seta from 1 st parapodium, $\times 840 ; \mathrm{p}$, pseudocompound seta from 1st parapodium of an other individual, $\times 840$; $\mathrm{q}$, pseudocompound seta from median parapodium, $\times 840 ; \mathrm{r}$, inferior simple seta from posterior parapodium, $\times 840$; s, acicula, $\times 840$. 


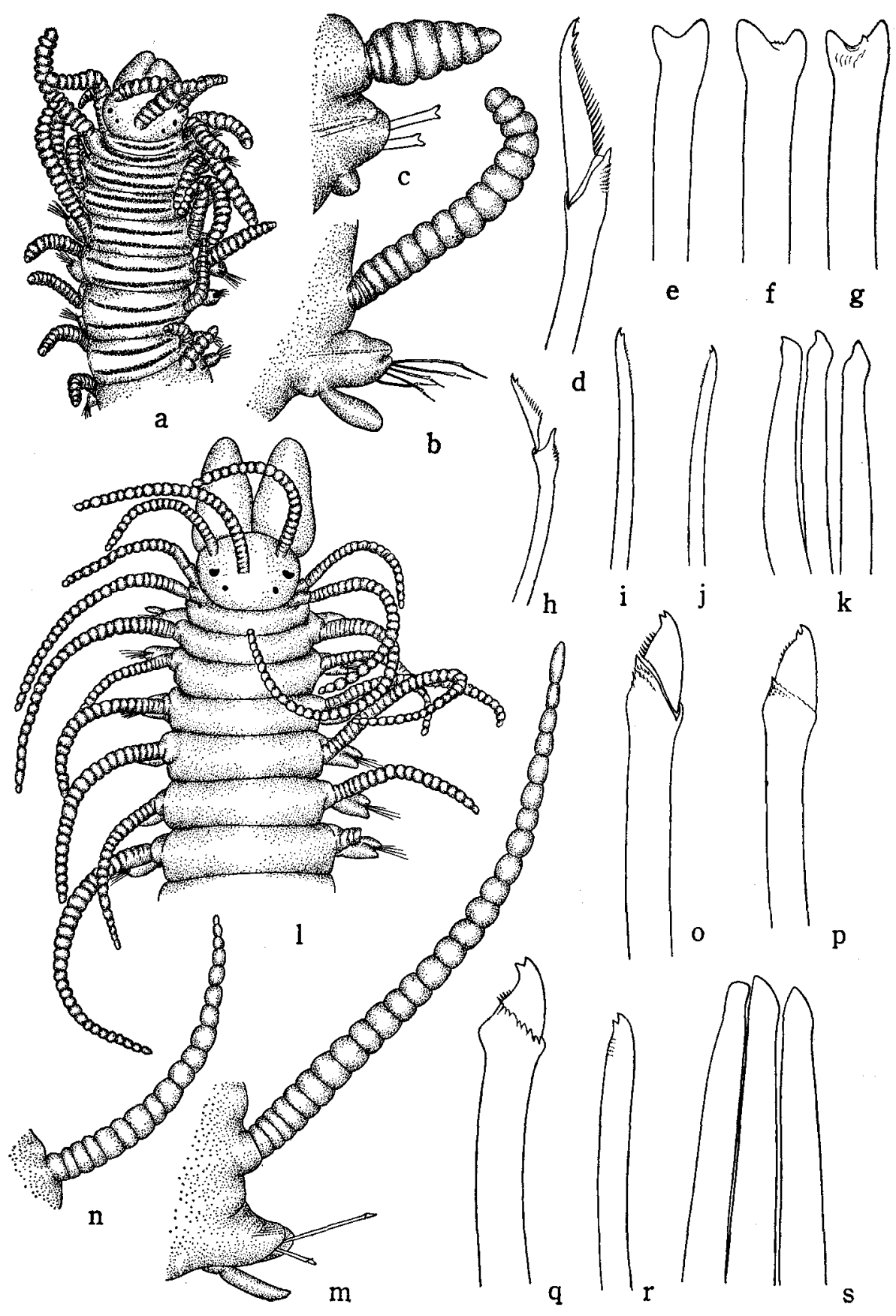


median antenna arises between the posterior eyes; it has 13 annulations. Lateral antennae arise from anterior margin of the prostomium and each has 10 to 11 annulations. Palpi are subtriangular and about as long as the prostomium; they are fused at their bases. The pharynx is surrounded by 10 soft papillae and has a middorsal tooth in its inner wall. The proventriculus is ellipsoidal and extends through setigerous segment 10 to 15 . Dorsal cirri in the anterior region of the body are slender and about as long as the body is wide; each has 13 to 18 annulations (fig. b). Those in the median and posterior region are short and club-shaped; they are half to one-third as long as the body is wide, and each has 6 or 7 annulations (fig. c). Each of first sixteen parapodia has a fascicle of compound setae; the appendage is distally bifid and has serrations along the cutting margin (fig. d). Thereafter the compound setae are replaced by two to three stout, bifurcated simple setae (figs. $\mathrm{e}, \mathrm{f}, \mathrm{g})$; their concave tips are smooth or have minute teeth. In posterior parapodia these simple setae are again replaced by compound setae (fig. $\mathbf{h}$ ) similar to but slenderer than the anterior setae. In addition, there are two distally bifid simple setae with fine serrations along one side of the shaft, occurring one in superior and one in inferior positions (figs. $i, j$ ); the first is just above the aciculum. Acicula number two to four and each is distally hooked (fig. k). The pygidium has two long anal cirri.

The species is new to Japan.

Distribution: Mediterranean Sea; British Isles; France; Red Sea; Indian Ocean; West and South Africa; Massachusetts; southern California to Panama; southern Japan.

\section{Syllis spongiphila VERRILL, 1885}

(Text-fig. 49, 1-s)

Syllis spongiphila Verrill, 1885, p. 435; Hartman, 1944, p. 339, pl. 24, fig. 10; Pettibone, 1963, pp. 114-115, fig. $30, \mathrm{~g}, \mathrm{~h}$.

Syllis sclerolaema Ehlers, 1901, p. 86, pl. 10, figs. 1, 2; Monro, 1930, p. 102, fig. 35; Berkeley and Berkeley, 1938, p. 40, fig. 5; Hartman, 1953, p. 20, fig. 2; 1964, p. 92; Uschakov, 1955, p. 179, fig. 50, d; Imajima and Hartman, 1964, pp. 122-124, pl. 28, figs. i, j, pl. 29, figs. a-i. Syllis (Typosyllis) sclerolaema WESENBERG-Lund, 1962, p. 54, fig. 15.

Collection: Off Shirikishinai, in 120-140 m; off Cape Shiriyazaki, in 140-350 m, attached to the surfaces of Mytilus, sponges and stones; Uraga Strait, in $40-80 \mathrm{~m}$.

Description: The largest specimen measures $27 \mathrm{~mm}$ long and $1.5 \mathrm{~mm}$ wide including parapodia; it consists of 90 setigerous segments.

The pharynx is everted in most individuals. The body is pale yellow and there are no color markings. The prostomium is subglobular, slightly wider than long; there are two pairs of eyes, the anterior pair is the larger. Palpi are subtriangular, and longer than the prostomium; they are separated from each other (fig. 1). A median antenna arises from the center of the prostomium and has 25 to 30 annulations. 
Lateral antennae are inserted in front of the anterior eyes. The pharynx is distally surrounded by 10 soft papillae and has a middorsal, chitinized tooth. The proventriculus is ellipsoidal and extends from segment 14 to 22. Dorsal tentacular cirri on the first segment are as long as the median antenna and ventral cirri are about twothirds as long as the dorsal one. The first dorsal cirri are slenderer and each has 30 to 36 annulations. The second are about half as long as the first ones and have about 20 annulations. The succeeding dorsal cirri alternate in length, having 26 to 45 in long (fig. $\mathrm{m}$ ) and 19 to 35 annulations in short (fig. $\mathrm{n}$ ) ones. Parapodia are conical and have a setal fascicle. In typical individuals the anterior parapodia have 3 to 5 clearly articulated, compound setae; the appendage is distally bifid and has minute serrations along the cutting margin (fig. o). Other specimens have a fascicle of pseudocompound setae in anterior parapodia (fig. p). These compound setae in typical individuals are replaced in 6 to 8 pseudocompound seate in median and posterior parapodia (fig. q). Posterior parapodia have a slender, bifid simple seta inferiorly (fig. r). Ventral cirri are slender and digitate. In middle parapodia acicula are hooked and number about 3 (fig. s) to 4 in a fascicle. The pygidium has two long anal cirri.

Through the courtesy of the United States National Museum three co-type specimens of Syllis spongiphila VerriLl (1885) were examined; they were taken at Fish Hawk Sta. 872 in 1880, off Marthas Vineyard, Massachusettes, in 86 fms. $S$. spongiphila has three kinds of setae; compound and pseudocompound with short appendage, and simple seta; their appendages are distally bifid.

The holotype specimen of Syllis sclerolaema EHLERs (1901) from South America was borrowed from the Naturhistoriska Riksmuseet in Stockholm. Both of these lots agree with Syllis spongiphila Verrill. Syllis sclerolaema Imajima and Hartman (1964) from Japan is also referred to this species.

\section{Sacconereis stage}

Occurrence: Off Shirikishinai, in surface tows, with plankton net in August.

This stage was described by WESENBERG-Lund (1962) for specimens from Chile and by Imajima and Hartman (1964, pp. 123-124) for some from Hokkaido.

Distribution: Massachusettes; Falkland Islands; Chile; western Canada; Okhotsk Sea; Japan.

\section{Syllis ramosa McInTosh, 1879}

Syllis ramosa McIntosh, 1885, pp. 198-205, pl. 31, fig. 1; pl. 33, figs. 11-14; pl. 15a, figs. 18-19; pl. 16a, fig. 1; pl. 34a, figs. 8-10, 12, 13; IzuKa, 1912, pp. 187-190, pl. 20, figs. 7,8; ImajıM and Hartman, 1964, p. 122.

Occurrence: Sagami Bay, in 100 fms.; Suruga Bay, in 90 fms., in hexactinellid sponges. 
Diagnosis: The body is much branched and divided as a result of both lateral and posterior budding; its width is 0.3 to $0.7 \mathrm{~mm}$. Color in life is rose-red. The prostomium is broader than long and has two pairs of eyes. Palpi are subtriangular and about as long as the prostomium. A median antenna arises from the center of the prostomium and extends a little beyond the anterior tip of the palpi. Lateral antennae arise from the anterior margin of the prostomium and are slightly shorter than the median one. Dorsal cirri are alternately long with 28 and short with 15 annulations. The setigerous lobe is conical and has compound setae with a falcigerous terminal appendage incompletely separated from the shaft. Ventral cirri are broad and short. Acicula occurs singly.

Distribution: Philippine Island; Arafura Sea, in 140 fms.; off central Japan, in $90-100 \mathrm{fms}$.

(To be continued.) 